\title{
Reflections on the development of the FASB's and IASB's expected-loss methods of accounting for credit losses
}

\author{
Noor Hashim \\ Weijia Li \\ John O'Hanlon \\ Lancaster University Management School
}

24 July 2018

This paper is based on a presentation at an Accounting and Business Research symposium on The Role of Accounting Information in Debt Markets at the European Accounting Association Congress, Valencia (May 2017). The paper is informed by work carried out within a project for which some results are reported in an ICAEW research briefing (O'Hanlon et al. 2018). The authors gratefully acknowledge the financial support of the ICAEW's Charitable Trusts for that project. This paper has benefited from the comments of Kees Camfferman on a preliminary version and from the detailed comments and suggestions of an anonymous reviewer.

Address for correspondence:

John O'Hanlon, Department of Accounting and Finance, Lancaster University Management School, Lancaster University, Lancaster LA1 4YX, UK.

e-mail: $\quad$ j.ohanlon@lancaster.ac.uk

Telephone: $\quad 44(0) 1524593631$

Fax: $\quad 44(0) 1524847321$ 


\title{
Reflections on the development of the FASB's and IASB's expected-loss methods of accounting for credit losses
}

\begin{abstract}
After the financial and banking crisis of the late 2000s, the FASB and the IASB aimed to develop methods of accounting for credit losses that would give more timely recognition of those losses. The IASB (in 2009) and the FASB (in 2010) each initially issued its own exposure draft proposing separate approaches to achieving this. They then attempted to agree a converged expected-lossbased method for accounting for credit losses, but failed to achieve convergence. They then each issued an accounting standard that included its own expected-loss method, with effective dates of 2018 for the IASB and 2020/21 for the FASB. This paper provides an overview of the development of proposals and standards in relation to accounting for credit losses issued by the standard setters from 2009 to 2016. It then offers reflections on difficulties that the standard setters faced in this area and on problems that might arise after the new standards become effective. It raises the question of whether a route based on 'expected loss', which in relation to credit losses is a concept that originally became prominent for the purpose of setting banks' capital requirements, was helpful to the process of improving the accounting for credit losses.
\end{abstract}

Keywords: financial accounting; impairment; expected loss; incurred loss; convergence 


\section{Reflections on the development of the FASB's and IASB's expected-loss methods of accounting for credit losses}

\section{Introduction}

The financial and banking crisis of the late 2000s prompted the Financial Accounting Standards Board (FASB) and the International Accounting Standards Board (IASB) to emphasise jointly 'the importance of working cooperatively and in an internationally coordinated manner to consider accounting issues emerging from the crisis' and to say that 'the FASB and the IASB recognize that the urgency of the credit crisis requires unprecedented action'. ${ }^{1}$ An issue that attracted particular attention was a perceived lack of timeliness in the then-current methods of accounting for credit losses, which is a highly material item for banks. ${ }^{2}$ The FASB and the IASB moved quickly to address this issue. In light of elements of the history of accounting for credit losses and relevant prior literature, we reflect on the process that standard setters went through in the aftermath of the crisis in order to achieve more timely accounting recognition of credit losses. Within this, we consider the difficulties that the standard setters faced, including in relation to their failure to achieve a converged common solution on accounting for credit losses.

At the time of the financial and banking crisis, both U.S. GAAP and IFRS required that credit losses should be accounted for using incurred-loss (hereinafter, IL) methods: credit losses should only be recognised where there was evidence based on past events that a loss had been incurred. The IL methods in place at that time were more heavily weighted towards limiting earnings management and the associated overstatement of loss allowances than towards permitting the exercise of discretion that might facilitate timely recognition of credit losses and ensure loss-allowance adequacy. At the time of the crisis, concern that the restrictive IL methods had contributed to delay in recognition of credit losses prior to the crisis prompted calls for more forward-looking methods that would result in the more timely 
recognition of losses, including from a prudential-regulatory perspective from the Financial Stability Board's report to G20 leaders (Financial Stability Board 2009) and the Basel Committee on Banking Supervision (hereinafter, BCBS) (BCBS, 2009). Consistent with advice from these sources and from the Financial Crisis Advisory Group (2009), the FASB and the IASB each pursued the development of more forward-looking methods of accounting for credit losses, including methods described as expected-loss (hereinafter, EL) methods. With regard to accounting for credit losses, the crisis appears to have prompted a shift in relative emphasis away from limiting earnings management and the associated overstatement of loss allowances and towards permitting the exercise of discretion that might facilitate timely recognition of credit losses and help to ensure that loss allowances are adequate.

The standard setters' process of developing methods that would lead to the more timely recognition of credit losses included the initial issue of separate IASB and FASB exposure drafts (IASB 2009, FASB 2010a), the issue of a joint supplementary document and follow-up proposals aimed at achieving a converged common solution (FASB/IASB 2011a, b), and the eventual failure of the attempt to achieve convergence. The standard setters then issued separate final exposure drafts (FASB 2012, IASB 2013a) and separate accounting standards (IASB 2014a, FASB 2016) with an effective date of 2018 for the IASB and 2020 or 2021 for the FASB.

Within their development of more timely methods of accounting for credit losses, the standard setters aimed to address the issue of the breadth of the information set that could be used to support the recognition of credit-loss impairment. They also aimed to address the perhaps less obvious issue that, when loans are made, the lender expects to suffer some asyet-unidentified credit losses that are compensated within the interest revenue that is typically accrued in full from year 1 onwards. Under the IL regimes in place, recognition of the associated initially-expected losses was delayed until loss events occurred, which typically 
resulted in some of the credit-premium-inclusive interest revenue being recognised in advance of the associated losses. In their initial exposure drafts (IASB 2009, FASB 2010a), the two standard setters each proposed a credit-loss-accounting method that would allow expected losses to be recognised in advance of the occurrence of the type of loss events required by pre-existing IL methods. The methods proposed in those two exposure drafts were based on different objectives. The FASB's objective was to ensure that loss allowances at each reporting date were sufficient to cover all estimated credit losses for the remaining life of in-scope financial assets. This led to a proposed method involving the establishment of loss allowances at the first reporting date after origination or purchase, sometimes referred to as 'day 1', which would immediately reflect initial expectations of all future credit losses expected to occur over the full contractual life of assets. The IASB's objective was to reflect initially-expected credit losses within the calculation of the effective interest rate on financial assets. This led to a proposed method that explicitly linked initially-expected credit losses with the pricing of financial assets at origination, and would result in the recognition of initially-expected losses being spread over the life of assets. Like the FASB's proposed method, this method would require credit losses to be recognised in advance of the type of loss events required under pre-existing IL methods. However, it was less conservative than the FASB's proposed method in that recognition of initially-expected losses would be spread over the life of assets rather than occurring immediately at day 1. The initial IASB method was widely regarded as conceptually strong in the sense that it reflected the economic substance of the relationship between the contractual interest rate and initially-expected losses. ${ }^{3}$ However, it was also widely regarded as posing a significant implementation challenge.

Subsequent joint deliberations by the FASB and the IASB based on FASB/IASB (2011a, b) were aimed at achieving a compromise converged solution that would partially 
address the objectives of each standard setter. Within these joint deliberations, the FASB and the IASB achieved straightforward and converged agreement that the information set that could be used to support credit-loss impairment would henceforth be broadened to include reasonable and supportable forecasts. This should address to a significant degree the concerns raised in the aftermath of the financial and banking crisis about delay in the accounting recognition of information about credit losses. However, the standard setters encountered a serious problem in their attempts to reach a converged solution for the treatment of initiallyexpected losses, and this contributed significantly to their inability to achieve a converged overall solution with respect to accounting for credit losses. The joint deliberations eliminated from consideration methods that explicitly spread the recognition of initiallyexpected losses across time. They produced a proposal that financial assets should be categorised with regard to whether or not their credit quality had significantly deteriorated since initial recognition: at each reporting date, allowances would recognise lifetime expected losses for assets that had significantly deteriorated since initial recognition ('bad book'); at each reporting date, including day 1 , they would recognise 12-month expected losses for assets that had not significantly deteriorated since initial recognition ('good book'). The IASB accepted this proposal, seeing the 12-month allowance for good-book assets as a means of achieving in a practicable way an approximation to the recognition of initially-expected losses over time, which was a central feature of IASB (2009). However, after extensive involvement in the deliberations, the FASB indicated that it could not accept this proposal and that it could only accept full recognition at each reporting date, including at day 1 , of all expected losses over the full contractual life of assets. The IASB's preferred approach was seen by the FASB as insufficiently conservative; the FASB's preferred approach was seen by the IASB as excessively conservative. There is evidence that the FASB's more conservative preference was due in part to pre-existing practice that reflected prudential-regulatory-related 
influence. After their failure to agree on this issue, the two standard setters proceeded to develop standards containing separate EL methods based on their respective preferences (IASB 2014a, FASB 2016). The process of developing the FASB and IASB standards on credit-loss impairment has been controversial both because of the failure to achieve a converged common solution and because of some of the proposals themselves. Both standard setters' requirements for the immediate establishment of loss allowances at day 1, 12-month expected losses in the case of the IASB and full-contractual-life losses in the case of the FASB, attracted significant criticism on conceptual grounds.

In this paper, we describe the events outlined above in the context of the history of accounting for credit losses and relevant prior literature and drawing on our confidential conversations with senior observers of the process. We then highlight two issues that may give rise to problems when the new credit-loss-impairment standards are implemented: the FASB's requirement for lifetime loss allowances and the day-1 loss requirements of both standard setters. We then consider whether, in light of issues arising during the development of the new EL credit-loss-impairment methods, improved methods of accounting for credit losses might have been more straightforwardly achieved through an alternative route to the type of EL route that was followed. In particular, we raise the question of whether, after the elimination from consideration of spreading-based EL approaches that did not involve day-1 losses, satisfactory more-forward-looking methods of accounting for credit losses that did not involve day-1 losses and that might have presented a lower barrier to FASB/IASB convergence might have been developed by following a less radical broader-information-setbased modified-IL-type route rather than by continuing to follow an EL route.

The paper is structured as follows. Section 2 provides background on the IL method of accounting for credit losses under U.S. GAAP and IFRS, provides background on bank regulation relating to credit losses and provides an outline of elements of prior academic 
literature that are relevant to the matters addressed in this paper. Section 3 outlines the development since 2009 by the FASB and the IASB of more timely methods of accounting for credit-loss impairment, including with reference to important elements of feedback on the standard setters' various proposal documents. Section 4 discusses issues that have arisen during the standard setters' development of their EL methods of accounting for credit losses that may present problems when the standards become effective. Section 5 considers whether a route based on EL was helpful to the process of improving the accounting for credit losses. Section 6 concludes.

\section{Background and literature review}

This section provides a summary of background and literature relevant to the events considered in this paper. Subsection 2.1 provides a summary of the history of the pre-existing IL methods of accounting for credit losses and of the pressure in the wake of the financial and banking crisis of the late 2000 s to replace them by more forward-looking methods. Subsection 2.2 provides some background on bank regulation that relates to credit losses. Subsection 2.3 provides a summary of relevant academic literature.

\subsection{The incurred-loss method of accounting for credit-loss impairment}

At the time of the financial and banking crisis of the late 2000s, the IL method for credit-loss impairment, which required that the recognition of loan losses should be supported by evidence that a loss had been incurred, was established in U.S. GAAP and in IFRS. This subsection provides some background on the IL methods in U.S. GAAP and IFRS that is relevant to the events considered in this paper. 


\subsubsection{U.S. GAAP: Incurred-loss}

The history of IL in U.S. GAAP includes action motivated by the perceived need to constrain discretion that might allow systematic delay in loan-loss recognition and understatement of loss allowances and, subsequently, action motivated by the perceived need to constrain discretion that might allow systematic overstatement of loss allowances. The latter of these appears to have contributed to criticism at the time of the financial and banking crisis of the late 2000s of the lack of timeliness of pre-existing methods of accounting for credit losses.

From 1975, SFAS 5 (FASB 1975) provided guidance on recognition of losses on receivables including loans. It included the following requirement:

An estimated loss from a loss contingency (as defined in paragraph 1) shall be accrued by a charge to income if both of the following conditions are met:

a. Information available prior to issuance of the financial statements indicates that it is probable that an asset had been impaired or a liability had been incurred at the date of the financial statements. It is implicit in this condition that it must be probable that one or more future events will occur confirming the fact of the loss.

b. The amount of loss can be reasonably estimated. (FASB 1975, paragraph 8)

Following the savings and loan crisis of the late 1980s, SFAS 5 was criticised for being ambiguous and so flexible that financially weak banks were able to manage earnings upwards by delaying recognition of losses (GAO 1991, GAO 1992). In May 1993, the FASB issued SFAS 114 (FASB 1993a). This was aimed at providing clearer and more consistent guidance on accounting for impairment of loans, other than small homogeneous loans collectively evaluated for impairment, including with respect to issues raised in GAO (1992). The criterion for recognition of impairment in SFAS 114 was consistent with that in SFAS 5, but the more specific guidance might have been expected to reduce the danger referred to by GAO (1992) that discretion might be used inappropriately in order to delay the recognition of loan losses. SFAS 114 (FASB 1993a) included the following reminder aimed at avoiding unduly restrictive interpretation of the IL requirement of FASB (1975): 
The term probable is further described in paragraph 84 of Statement 5, which states:

The conditions for accrual in paragraph 8 [of Statement 5] are not inconsistent with the accounting concept of conservatism. Those conditions are not intended to be so rigid that they require virtual certainty before a loss is accrued. They require only that it be probable that an asset has been impaired or a liability has been incurred and that the amount of loss be reasonably estimable. (FASB 1993a, paragraph 10)

Also in May 1993, the FASB issued SFAS 115 (FASB 1993b), which was motivated in part by a perceived need for more consistent guidance on impairment of debt securities. The IL credit-loss impairment requirements of SFAS 5, SFAS 114 and SFAS 115 were included in the pre-FASB (2016) FASB codification topics 450, 310 and 320, respectively. FASB codification topic 310 includes the following with respect to loan impairment:

The following provides an overview of generally accepted accounting principles (GAAP) for loan impairment:

a. It is usually difficult, even with hindsight, to identify any single event that made a particular loan uncollectible. However, the concept in GAAP is that impairment of receivables shall be recognized when, based on all available information, it is probable that a loss has been incurred based on past events and conditions existing at the date of the financial statements.

b. Losses shall not be recognized before it is probable that they have been incurred, even though it may be probable based on past experience that losses will be incurred in the future. It is inappropriate to consider possible or expected future trends that may lead to additional losses. (FASB Codification, paragraph 310-10-35-4)

In the years following the issue of SFAS 114 and in contrast to the concern about understatement of losses raised prior to the issue of SFAS 114, concern was expressed by SEC representatives that U.S. banks might be using discretion inappropriately in order to facilitate earnings management through overstatement of loan-loss allowances. ${ }^{4}$ In 1998 the SEC questioned the loan-loss accounting of SunTrust Banks Inc. and required it to reduce its loan-loss allowance by $\$ 100$ million. During the SunTrust investigation, the SEC also sent letters to a number of U.S. banks questioning their loan-loss allowances (Meyer 1999). These actions were viewed as a warning signal to all U.S. banks that the SEC would not tolerate over-provisioning for loan losses during good times. However, U.S. bank regulators did not 
believe that the loan-loss allowances of U.S. banks were systematically excessive. They were concerned that the SEC's actions might create a perception that loan-loss allowances would have to be reduced, and claimed that any general downward pressure on allowances could have a serious effect on the safety of the U.S. banking system (Meyer 1999, Rushton 1999). There was concern on the part of U.S. banks that they might be caught in a conflict between the SEC and U.S. bank regulators, with the former requiring lower allowances and the latter requiring higher allowances (Wall and Koch 2000, pp. 1-2). There ensued a debate between the SEC, the FASB and U.S. bank regulators on accounting for credit losses. Then, in July 2001, the SEC and bank regulators stated their joint position on loan-loss allowances in SAB $102^{5}$ and FFIEC (2001), respectively, which required banks to estimate loan-loss allowances in accordance with GAAP with enhanced documentation to support their allowance estimates. The joint guidance of 2001 might be seen as a tightening of IL loan-loss recognition requirements or, at least, as a reaffirmation of the IL principle in U.S. GAAP (Camfferman 2015, p. 8).

Such tightening might be expected to limit loan-loss-related earnings management, but at the cost of reduced timeliness in loan-loss recognition. Evidence in Balla and Rose (2015) and Beck and Narayanamoorthy (2013) suggests that this may have occurred. Balla and Rose (2015) find that, after the guidance of 2001, the relationship between earnings and loan-loss expense weakened, indicating reduced earnings management; however, they also claim that the guidance constrained U.S. banks' early recognition of losses in the years prior to the crisis of the late 2000s. Beck and Narayanamoorthy (2013) report that, after the SAB 102 and FFIEC (2001) guidance became effective, the estimation of banks' loan-loss allowances appeared to become more reliant on past charge-offs and less reliant on current non-accrual loans. This was accompanied by a decline in the informativeness, as proxied by the ability to explain future losses, of the loss allowances of weak banks after SAB 102 and 
FFIEC (2001) became effective and especially immediately before the financial and banking crisis. The authors suggest two possible reasons for this. First, in the relatively unstable environment faced by weak banks, more forward-looking indicators such as non-accrual loans are likely to be more beneficial than backward-looking indicators such as past chargeoffs in enhancing the informativeness of loss allowances. Second, although SAB 102 and FFIEC (2001) may have been effective in constraining overstatement of loss allowances, they could not be expected to be effective in constraining weak banks' management of earnings through delay in the recognition of loan losses. ${ }^{6}$

The perception that effects of the sort indicated by Balla and Rose (2015) and Beck and Narayanamoorthy (2013) were at work prior to the crisis led to a swing, in the aftermath of the financial and banking crisis, away from concern about earnings management and towards concern about timeliness of loss recognition and loss-allowance adequacy. This was reflected in, among other things, the comments made in 2009 by the Comptroller of the Currency, John Dugan, to the effect that, in the prolonged period of benign economic conditions before the late-2000s crisis, a number of banks had felt constrained in their ability to document adequately the judgmental factors that might have allowed them to make provisions that were higher than historical experience would imply. ${ }^{7}$

\subsubsection{IFRS: Incurred-loss}

In common with the history of IL in U.S. GAAP, the history of IL in IFRS includes action that appears to have been motivated by the perceived need to constrain discretion that might allow earnings management. It also includes some indication of the lack of a clear-cut distinction between IL and EL that we refer to later in this paper. 
Prior to the 2003 revision of IAS 39, the word 'incurred' was not used in IAS 39 in connection with impairment relating to credit losses. The requirements of the pre-2003 version of IAS 39 included the following:

A financial asset is impaired if its carrying amount is greater than its estimated recoverable amount. An enterprise should assess at each balance sheet date whether there is any objective evidence that a financial asset or group of assets may be impaired. If any such evidence exists, the enterprise should estimate the recoverable amount of that asset or group of assets and recognise any impairment loss [...] Objective evidence that a financial asset or group of assets is impaired or uncollectable includes information that comes to the attention of the holder of the asset about:

a. significant financial difficulty of the issuer;

b. an actual breach of contract, such as a default or delinquency in interest or principal payments;

c. granting by the lender to the borrower, for economic or legal reasons relating to the borrower's financial difficulty, of a concession that the lender would not otherwise consider;

d. a high probability of bankruptcy or other financial reorganisation of the issuer;

e. recognition of an impairment loss on that asset in a prior financial reporting period;

f. the disappearance of an active market for that financial asset due to financial difficulties; or

g. a historical pattern of collections of accounts receivable that indicates that the entire face amount of a portfolio of accounts receivable will not be collected.

The disappearance of an active market because an enterprise's securities are no longer publicly traded is not evidence of impairment. A downgrade of an enterprise's credit rating is not, of itself, evidence of impairment, though it may be evidence of impairment when considered with other available information. (IASB 2000, paragraphs 109-110)

Although the term 'incurred' was not used in the credit-loss impairment requirements of the pre-2003 version of IAS 39, the evidence requirements quoted above were similar to those of the 2003 revision of IAS 39, which are commonly regarded as IL.

In a detailed review of events related to the 2003 revision of the credit-loss impairment requirements of IAS 39, Camfferman (2015, p. 4) notes that the practice of making a distinction between IL and EL in the context of accounting for credit losses only started to become common at the time of the deliberations leading up to that 2003 revision. ${ }^{8}$ However, the distinguishing features of EL relative to IL in relation to accounting for credit 
losses were not clear at that time, as was illustrated by the following from the Basis for Conclusions of the 2003 revision of IAS 39:

Some respondents to the Exposure Draft were confused about whether the Exposure Draft reflected an 'incurred loss' model or an 'expected loss' model. (IASB 2003, paragraph BC108)

Camfferman (2015) observes that the IASB's deliberations in relation to the 2003 revision of IAS 39 tended at times towards more forward-looking EL-type features and tended at other times towards strengthening and emphasising the pre-existing loss-event-focused IL-type features of the IAS 39 requirements. The IASB eventually came down on the side of an affirmation of IL. Camfferman (2015) comments as follows that the desirability of convergence with U.S. GAAP and the need to constrain earnings management were influential in leading to that outcome:

The IASB acted under time pressure to improve the standards inherited from the IASC for the first mass adoption of IFRS in 2005, with the result that the wording of the standard as finally approved by the Board, with respect to loan impairment, differed considerably from the proposals on which constituents had been asked to comment. In the end, the importance attached to convergence with U.S. Generally Accepted Accounting Principles (U.S. GAAP) and the prevailing of an anti-abuse perspective on the issue seem to have tilted the Board towards a strict incurred-loss model. (Camfferman 2015, p. 3)

The revised IAS 39 impairment requirements were as follows:

A financial asset or a group of financial assets is impaired and impairment losses are incurred if, and only if, there is objective evidence of impairment as a result of one or more events that occurred after the initial recognition of the asset (a 'loss event') and that loss event (or events) has an impact on the estimated future cash flows of the financial asset or group of financial assets that can be reliably estimated. [...] Losses expected as a result of future events, no matter how likely, are not recognised. Objective evidence that a financial asset or group of assets is impaired includes observable data that comes to the attention of the holder of the asset about the following loss events:

a. significant financial difficulty of the issuer or obligor;

b. a breach of contract, such as a default or delinquency in interest or principal payments;

c. the lender, for economic or legal reasons relating to the borrower's financial difficulty, granting to the borrower a concession that the lender would not otherwise consider; 
d. it becoming probable that the borrower will enter bankruptcy or other financial reorganisation;

e. the disappearance of an active market for that financial asset because of financial difficulties; or

f. observable data indicating that there is a measurable decrease in the estimated future cash flows from a group of financial assets since the initial recognition of those assets, although the decrease cannot yet be identified with the individual financial assets in the group, including:

i. adverse changes in the payment status of borrowers in the group (e.g., an increased number of delayed payments or an increased number of credit card borrowers who have reached their credit limit and are paying the minimum monthly amount); or

ii. national or local economic conditions that correlate with defaults on the assets in the group (e.g., an increase in the unemployment rate in the geographical area of the borrowers, a decrease in property prices for mortgages in the relevant area, a decrease in oil prices for loan assets to oil producers, or adverse changes in industry conditions that affect the borrowers in the group). (IASB 2003, paragraph 59)

Significant changes introduced in the 2003 revision of IAS 39, which could be seen as a reaffirmation of the restrictions of IL, included a statement that impairment should be based on 'one or more events that occurred after the initial recognition of the asset (a 'loss event')', the explicit prohibition of recognition of 'losses in respect of future events, no matter how likely' and the inclusion of more detail on evidence requirements for collective provisioning reflected in the replacement of sub-paragraph $(\mathrm{g})$ in the pre-2003 version by sub-paragraph (f) in the revised version.

As with the U.S. history referred to in the previous subsection, events described here contributed to setting the scene for a swing, in the aftermath of the financial and banking crisis, away from concern about earnings management and towards concern about timeliness of loss recognition and loss-allowance adequacy.

\subsubsection{Indications of differences between U.S. GAAP and IFRS applications of incurred loss}

There is evidence that IL methods as applied in the U.S. gave rise to higher loss allowances on average, other things equal, than outside the U.S. Our confidential conversations with 
senior observers of the development of the FASB and IASB EL methods indicated a widelyheld view that the recognition of loan-losses under the IL approach as applied in the U.S., in particular for smaller banks, tended to be at the more conservative end (i.e., higher loss allowances) of what is acceptable under the IL method and, other things equal, more conservative than in countries using IFRS. A letter written by the American Bankers Association (ABA) in response to the FASB (2012) exposure draft contained a comment consistent with the view that the hurdle for recognition of loan impairments may have been lower under the FASB's IL method than under the IASB's IL method: ${ }^{9}$

Loss events, appear to be defined as an earlier point in time under U.S. accounting practices than under International Financial Reporting Standards (IFRS). Under IFRS, the term "loss event" is defined within IAS 39. [...] In U.S. GAAP, there is generally no discussion of loss events as they relate to loans. However, within bank practices, as guided by banking agencies, the following are normally considered "loss events":

- Borrower loses major source of income. For a consumer, it is normally his/her employment. For a commercial borrower, it is a major customer.

- Overall, financial results put repayment at risk, as evidenced in a commercial loan review.

- Property value deterioration, as evidenced when loan to value ratios exceed $100 \%$.

Thus, U.S. practice would likely refer to IAS 39 "loss events" not as loss events, but as loss identification events, which are generally subsequent to loss events. It is indeed a challenge to estimate when a loss event has occurred in the U.S., but there is general agreement that the loss event happens prior to default. Thus, the foundation for defining when a loss is a loss under IFRS naturally leads to later loss recognition than in the U.S.

Related to this, an ABA document of June 2016 noted evidence that, in determining their loss allowances, U.S. banks make substantially greater use than European banks of assumptions that losses are 'incurred but not reported' (IBNR). ${ }^{10}$

As we describe later, differences of the type referred to above between pre-existing practice in the U.S. and elsewhere presented a challenging context for the attempt by the FASB and the IASB to develop a common solution for accounting for credit losses. The barrier created by the difference in pre-existing practice will have been particularly 
challenging in combination with the interaction between U.S. bank regulation and U.S. GAAP. $^{11}$

\subsubsection{Pressure to adopt expected-loss methods in accounting for credit losses}

We note above the observation in Camfferman (2015) that the IL/EL distinction in relation to accounting for credit losses only started to be made at the time of the 2003 revision of IAS 39 and was not very clear at the time. The discussion in Camfferman (2015) suggests that, even for the purpose of describing years later the events leading up to the 2003 revision, the IL/EL distinction is best conveyed by reference to 'positions on a continuum of approaches that allow greater or lesser scope for early loss recognition' (Camfferman 2015, p. 4): IL tends to be used in connection with backward-looking observable concepts such as 'loss events'; EL tends to be used in connection with forward-looking concepts such as 'recoverable amounts'; EL tends to be used to refer to methods involving the inclusion of expected credit losses in the calculation of the effective interest rate; EL tends to be used to refer to methods that recognise at portfolio level losses that may not yet be individually identified. The fact that it was thought easiest to convey the IL/EL distinction in relation to accounting for credit losses by giving indicative characteristics rather than by giving a definition of the distinction is indicative of lack of clarity in the distinction.

Despite a possible lack of clarity with regard to the IL/EL distinction in the context of accounting for credit losses, the calls in the aftermath of the banking and financial crisis for more timely accounting for credit losses included encouragement to consider EL models. Such encouragement came from the Financial Crisis Advisory Group in a report to standard setters in July 2009:

In the financial instruments project, the Boards should explore alternatives to the incurred loss model for loan loss provisioning that use more forwardlooking information. These alternatives include an expected loss model and a fair value model. (Financial Crisis Advisory Group 2009, p.7) 
From a prudential-regulatory perspective, it came from the Financial Stability Board in a report to G20 leaders in September 2009:

We strongly encourage the IASB and FASB to agree on improved converged standards that will:

- Incorporate a broader range of available credit information than existing provisioning requirements, so as to recognise credit losses in loan portfolios at an earlier stage as part of an effort to mitigate procyclicality. We are particularly supportive of continued work on impairment standards based on an expected loss model. (Financial Stability Board 2009, pp. 7-8)

Also from a prudential-regulatory perspective, it came from BCBS in August 2009:

Loan loss provisioning should be robust and based on sound methodologies that reflect expected credit losses in the banks' existing loan portfolio over the life of the portfolio... The accounting model for provisioning should allow early identification and recognition of losses by incorporating a broader range of available credit information than presently included in the incurred loss model and should result in an earlier identification of credit losses. (BCBS 2009, paragraph 12).

It is easy to understand why, in the aftermath of a financial and banking crisis in which lack of timeliness in accounting for credit losses had attracted attention, the replacement of a backward-looking restrictive IL method by a more forward-looking EL method would appear attractive. A rhetorical question asked by a speaker at a European Parliament hearing on IFRS 9 captures the immediately apparent attraction of the concept of EL in the context of accounting for credit losses: 'who would not want to provide for a loss, which is expected?' (Mike Ashley, European Parliament, 1 December 2015). ${ }^{12}$ Such rhetorical questions sometimes imply that the answer is not as straightforward as might first appear.

\subsection{Some background on bank regulation that relates to credit losses}

Events described in this paper relate in some ways to the interests of prudential regulators and therefore to any influence that prudential regulators might be perceived to have had on these events. In light of this, we provide in this subsection some background information on aspects 
of bank regulation that relate to credit losses. Much of bank regulation deals with the determination of the capital that banks are required to hold and with the measurement of the capital that they actually hold. These are a central focus of the various Basel accords (BCBS 1988, BCBS 2006, BCBS 2011). For the purposes of this paper, these accords provide a useful indicator of the interest that bank regulators might have in the issue of accounting for credit losses.

Under the Basel framework, the regulatory capital that a bank is required to hold is set by reference to the risk attached to its activities and is aimed at covering unexpected losses that, in light of that risk, might arise. A key principle underlying the measurement of actual regulatory capital is that it should be measured after deducting appropriate allowances for expected losses, thereby ensuring that capital is fully available to absorb unexpected losses. This principle has become blurred where regulatory-capital rules have permitted loss allowances recognised in banks' financial statements to be treated as part of regulatory capital. ${ }^{13}$ In the remainder of this subsection, we outline elements of the treatment of loanloss allowances under the various Basel accords.

The 1988 Basel 1 accord defined capital for bank-supervisory purposes as comprising two tiers: Tier 1, described as core capital; Tier 2 described as supplementary capital. Under Basel 1, general loss allowances, which along with other loss allowances reduced book equity and Tier 1 capital by their net-of-tax amount, were included in Tier 2 capital up to a maximum of $1.25 \%$ of risk-weighted assets (BCBS 1988, paragraphs 18 and 21).

The Basel 2 framework (BCBS 2004b, BCBS 2006) introduced three 'pillars' which, collectively, were aimed at promoting stronger risk-management practices in the banking industry: pillar 1 'Minimum Capital Requirements', which deals with the calculation of minimum capital requirements and with the measurement of regulatory capital, including with regard to the treatment of expected credit losses in the measurement of regulatory 
capital; pillar 2 'Supervisory Review Process', which relates to internal-control mechanisms with regard to risk and capital requirements; pillar 3 'Market Discipline', which is aimed at ensuring that disclosure is adequate to inform market participants about risk and capital requirements. Under the Basel 2 framework, credit risk for regulatory-capital purposes would be assessed either under the internal ratings-based (IRB) approach, under which approved banks could use their own internal rating systems to measure credit risk, or under the standardised approach, which would use external credit assessments. In the pre-Basel-2 consultations, when the introduction of up-front recognition of expected losses for regulatorycapital purposes first became a prominent issue, there was some debate about whether expected losses should be dealt with through the determination of required capital (i.e., as an addition to risk-weighted assets, the denominator of a regulatory-capital ratio) or through the measurement of actual capital (i.e., as a deduction from capital, the numerator of a regulatory-capital ratio). After objections to initial proposals to follow the former route, the latter route was eventually chosen (BCBS 2001a, b, BCBS 2003, BCBS 2004a Introduction). The resultant IRB approach in relation to loss allowances (termed here 'provisions') is described as follows in the Basel 2 framework document:

Banks using the IRB (internal ratings-based) approach [...] must compare (i) the amount of total eligible provisions, as defined in paragraph 380 , with (ii) the total expected losses amount as calculated within the IRB approach and defined in paragraph 375 . Where the total expected loss amount exceeds total eligible provisions, banks must deduct the difference. Deduction must be on the basis of 50\% from Tier 1 and 50\% from Tier 2 . Where the total expected loss amount is less than total eligible provisions, as explained in paragraphs 380 to 383 , banks may recognise the difference in Tier 2 capital up to a maximum of $0.6 \%$ of credit risk-weighted assets. (BCBS 2006, paragraph 43)

BCBS (2006, paragraph 43) also stated that, under the IRB approach, the Basel 1 treatment of general loan-loss allowances as part of Tier 2 capital would no longer be permitted. Under the Basel 2 standardised approach, the treatment of loan-loss allowances is as under Basel 1 
(BCBS 2006, paragraph 42), whereby general loan-loss allowances are included in Tier 2 capital up to a maximum of $1.25 \%$ of risk-weighted assets. ${ }^{14}$

Under the Basel 3 accord, issued in 2010 and revised in 2011 (BCBS 2011), the deduction from capital in respect of a shortfall of the stock of provisions relative to expected losses under the IRB approach should be made entirely within Common Equity Tier 1 capital, which is part of Tier 1 capital (BCBS 2011, paragraph 73). Where the total expected loss amount is less than total eligible provisions, banks may recognise the difference in Tier 2 capital up to a maximum of $0.6 \%$ of credit-risk-weighted assets (BCBS 2011, paragraph 61). Under the Basel 3 standardised approach, the treatment of loan-loss allowances is as under Basel 1 (BCBS 2011, paragraph 60).

From the foregoing, it can be seen that, although the loan-loss allowances on banks' balance sheets are over-ridden in some ways by bank-regulators' adjustments to regulatory capital, loan-loss allowances affect regulatory capital. For example, for banks following the Basel standardised approach, the net-of-tax loss allowance recognised in the balance sheet reduces Tier 1 capital directly and the gross-of-tax general allowance increases Tier 2 capital up to a maximum of $1.25 \%$ of risk-weighted assets. ${ }^{15}$ Furthermore, even for IRB banks, for which a Basel 3 regulatory expected-loss estimate that exceeds the accounting allowance over-rides the allowance, movements in the allowance directly affect Tier 1 regulatory capital if the allowance exceeds the regulatory expected-loss estimate (Kruger et al. 2018, p. 116). ${ }^{16}$ Also, we note that, although bank regulators typically have the power to write their own rules that over-ride accounting rules in the measurement of regulatory capital, Ryan and Keeley (2013, p. 69) observed that U.S. bank regulators appeared unwilling to do so in relation to U.S. GAAP as interpreted by the SEC in SAB 102. 


\subsection{Literature review}

The IL methods for accounting for credit losses that were in place under U.S. GAAP and IFRS at the time of the financial and banking crisis of the late 2000s were more heavily weighted towards limiting earnings management and the associated overstatement of loss allowances than towards permitting discretion that might facilitate timely recognition in loss allowances of information about likely credit losses. In part in response to advice from a prudential-regulatory perspective, the crisis prompted a shift in relative emphasis away from the former and towards the latter. This was reflected in the development of new EL-based methods of accounting for credit losses. ${ }^{17}$ In this subsection, we review elements of the prior literature that are relevant to these features of the events examined in this paper. We structure our review such as to focus on (i) elements of the literature on earnings management and capital management in relation to banks and (ii) elements of the literature on accounting conservatism and timeliness in relation to banks, including in relation to stability of the financial system. See also Giner and Mora (2018) for further consideration of the issues considered in our review and related issues, in particular in relation to the academic literature on accounting conservatism.

\subsubsection{Elements of the literature on earnings management and capital management in} relation to banks

The restrictions of the IL method of accounting for credit losses, criticised at the time of the financial and banking crisis of the late 2000s, could be attributed in part to the understandable importance previously attached to the restriction of opportunities for manipulation of creditloss expense that might be undertaken for earnings-management purposes.

There is a substantial body of evidence that such manipulation has occurred in order to manage either or both of earnings and regulatory capital. ${ }^{18}$ Moyer (1990) and Beatty et al. (1995) report evidence of loss-allowance-related regulatory-capital management in the U.S. 
prior to the implementation of the first Basel accord (Basel 1), when U.S. loan-loss allowances had a greater regulatory-capital-increasing benefit than after implementation of Basel 1. ${ }^{19}$ Kim and Kross (1998) and Ahmed et al. (1999) report evidence that such capital management was reduced in the post-Basel period after the regulatory-capital benefit was reduced. Further evidence of loss-allowance-related earnings and/or capital management in the U.S. is reported in Collins et al. (1995), Lobo and Yang (2001), Kanagaretnam et al. (2003), Kanagaretnam et al. (2004) and Liu and Ryan (2006). Huizinga and Laeven (2012) examine U.S. banks' use of accounting discretion during the crisis. They report evidence that such discretion, including with respect to loan-loss expense, was used to overstate book values of financial assets during the crisis. In contrast, Jin et al. (2016) report evidence that U.S. banks' discretion with respect to loan-loss expense prior to the crisis was used primarily for risk-management purposes through provision for future credit losses rather than for earnings-management-related purposes. Evidence of loss-allowance-related earnings and/or regulatory-capital management has also been reported for Japan (Shrieves and Dahl 2003), Australia (Anandarajan et al. 2007) and Spain (Perez et al. 2008). Hasan and Wall (2004) report evidence of loss allowances being used to manage earnings in a large number of countries. A multi-national study by Fonseca and Gonzalez (2008) reports that the use of loan-loss-related earnings smoothing varies predictably across countries in relation to factors including investor protection, disclosure, regulation and the degree of financial development. Another multi-national study by Bouvatier et al. (2014) reports that European banks with more concentrated ownership have used discretionary loan-loss expense to smooth their income, and that this effect is less strong in countries with stronger supervisory regimes that might be expected to limit opportunistic behaviour.

A number of studies focus on the trade-off between (i) constraints on discretion that might be used to manage earnings and (ii) facilitation of timely and informative reported 
credit-losses. We have already referred to the evidence in Balla and Rose (2015) and in Beck and Narayanamoorthy (2013) that the strengthening of IL-recognition requirements in the U.S. in the early 2000s reduced earnings management but placed constraints on banks' timely recognition of loan losses. In a similar vein, Gebhardt and Novotny-Farkas (2011) find that the IL restriction imposed through the adoption of IAS 39 (IASB 2003) by European banks reduced the extent to which loan losses were used to manage earnings but resulted in less timely loan-loss recognition. They questioned the desirability of restricted discretion under IAS 39 in light of its possible adverse consequences during the financial and banking crisis of the late 2000s. ${ }^{20}$ Marton and Runesson (2017) also find evidence that, compared with preexisting local GAAP, IAS 39 reduced the timeliness of loan-loss expense in the European Union. They find that loan-loss expense under the IAS 39 IL method predicts future credit losses, as measured by charge-offs, to a lesser extent than under local GAAP, consistent with the IL model reducing the timeliness of loss recognition. They find that the comparative advantage of local GAAP is stronger (i) under strict enforcement, (ii) in larger banks, which are likely to benefit from relatively high levels of specialised skills and system support, and (iii) in relatively profitable banks, where incentives to manage earnings may be relatively low. They note that their results suggest that introduction of more discretionary EL methods will need to be supported by appropriate enforcement mechanisms. In relation to post-crisis proposals for more discretionary and forward-looking credit-loss-accounting methods, Bushman and Williams (2012) point to the risk that the benefits from reduced procyclicality arising from such methods may be swamped by losses in transparency. They report evidence that discretion in loan-loss provisioning that is used for timely loss recognition enhances discipline over bank risk-taking but that discretion in loan-loss provisioning that is used for earnings-smoothing purposes dampens that discipline. Acharya and Ryan (2016) argue that, absent banks' exercise of discretion, an EL model should provide earlier warning of economic 
downturns than the IL model but that FASB (2012) would not suppress much if any volatility because it significantly broadens banks' discretion. Novotny-Farkas (2016) notes that the IFRS 9 EL model should have the beneficial effect of allowing earlier loss recognition and might enhance financial stability if it is implemented properly and consistently, but that the degree of discretion that it allows gives significant scope for earnings management.

The evidence summarised in this subsection indicates that there was some justification for standard setters to focus on restriction of earnings management in the creditloss accounting methods that they had in place prior to the crisis. It also indicates that there is reason to monitor the effects of the earnings-management opportunities created by the greater discretion permitted by the new EL methods relative to the pre-existing IL methods.

\subsubsection{Elements of the literature on accounting conservatism and timeliness in relation to banks}

During the standard setters' development of their EL methods of accounting for credit losses, a significant issue arose regarding the magnitude of loss allowances. As outlined in Section 1 and described more fully later in the paper, a significant cause of the failure of FASB/IASB convergence on accounting for credit losses was that the IASB's preferred method for the determination of loss allowances was seen by the FASB as insufficiently conservative, in that allowances for credit losses would not be established soon enough, and the FASB's preferred method was seen by the IASB as excessively conservative, in that allowances for credit losses would be established too soon. We now consider elements of the literature that are relevant to this matter. We do so under the headings of 'Conditional and unconditional conservatism' and 'Association between timeliness in recognition of credit losses and stability of the financial system'. 


\subsubsection{Conditional and unconditional conservatism}

It might be argued that a conservative focus on loss-allowance adequacy, at the potential risk of over-stating those allowances, is beneficial to the extent that it allows the exercise of prudence under conditions of uncertainty, leading to timely recognition of new information about credit losses. ${ }^{21}$ The type of news-dependent accounting conservatism envisaged here is sometimes termed 'conditional conservatism' (Ball and Shivakumar 2005; Beaver and Ryan 2005). The beneficial effects of this type of conservatism have been extensively examined in the accounting literature through asymmetric-timeliness measures of the sort pioneered by Basu (1997), which measure the extent to which bad news is recognised in financial statements more quickly than good news. It might also be argued that a conservative focus on loss-allowance adequacy, at the potential risk of over-stating those allowances, is not beneficial to the extent that it might introduce a substantial level of bias that is not only uninformative in itself but might also limit the extent to which movements in loss allowances reflect new information. The type of news-independent accounting conservatism envisaged here contributes to what is sometimes termed 'unconditional conservatism' (Ball and Shivakumar 2005; Beaver and Ryan 2005). As the distinction between conditional conservatism and unconditional conservatism is of some relevance to the events examined in this paper, we review briefly in this subsection some elements of the literature relating to these concepts.

There is much evidence in the general financial-reporting literature of the benefits of conditional conservatism. It has been found to be beneficial in addressing informationasymmetry problems, including through acceleration in the triggering of debt-covenant violations (Zhang 2008), facilitation of access to debt markets thereby alleviating underinvestment (Garcia Lara et al. 2016), addressing information requirements of debtholders of near-insolvent companies (Aier et al. 2014) and constraining behaviour by managers that may 
be detrimental to relatively uninformed outside equity investors (LaFond and Watts 2008). Beneficial effects of timely loss recognition documented in the general financial-reporting literature are also reflected in relation to financial institutions. Nichols et al. (2009) report evidence that, as predicted because of the greater information asymmetry that they face, public banks are more conditionally conservative than private banks. Vyas (2011) reports evidence that market prices of financial institutions reflect exposure to risky assets more quickly in the presence of timelier write-downs of those assets. Lim et al. (2015) report that conditional conservatism on the part of banks is associated with high reputation, enabling among other things the ability to charge higher interest to loan customers. Akins et al. (2017) find that timely loan-loss recognition constrains corruption in relation to banks' lending.

Conditional conservatism can be contrasted with news-independent or unconditional conservatism. Unconditional conservatism typically arises in a number of ways, of which commonly quoted examples are: (i) for long-lived assets, the use of depreciation/amortisation rates that exceed the economic rates; (ii) for internally-generated intangible assets, immediate expensing of the costs of developing those assets. The non-recognition of growth options and of the present value of monopoly returns is sometimes also quoted as an example of unconditional conservatism, but some see this as different in character from the two items referred to above (Ryan 2006, Roychowdhury and Watts 2007). An effect of newsindependent unconditional conservatism can be to introduce uninformative bias that restricts the extent to which informationally-valuable news-dependent conditional conservatism can be applied. Ball and Shivakumar (2005, pp. 90-91) refer to this potentially adverse effect in the context of contracting efficiency. ${ }^{22}$ 


\subsubsection{Association between timeliness in recognition of credit losses and stability of the}

financial system

Much of the evidence on the benefits of timely recognition of credit losses and resultant lossallowance adequacy relates to the stability of the financial system, which is of interest to prudential regulators. We consider this body of literature in the context of the consideration of the interest of prudential regulators in the issue of accounting for credit losses.

It has been argued that prudential regulators have an asymmetric loss function because understated loss allowances may contribute to bank failure, with consequent severe costs to bank regulators, whereas overstated allowances are unlikely to impose severe costs on regulators (Benston and Wall 2005). Pressure from taxpayers who may have to meet the financial cost of bank failures is also likely to contribute to this effect (Wall and Koch 2000 p. 15, Kane 1997). Prudential regulators might therefore be expected to be less averse to the overstatement of loss allowances than others with an interest in accounting for credit losses.

Prudential regulators' interest in loss allowances arises both through their role in relation to regulatory capital and through other mechanisms. It is convenient to consider the regulatory-capital-related role of loss allowances in the context of the Basel 2 framework, referred to earlier. As noted previously, in relation to the framework's pillar 1 'Minimum Capital Requirements', loan-loss allowances on banks' balance sheets are an input to the calculation of Tier 1 capital and Tier 2 capital. A number of studies report evidence that suggests that the direct effect of accounting for credit losses on regulatory capital, which could be characterised as a pillar-1-related effect, in combination with an asymmetric loss function could result in a preference on the part of prudential regulators for allowances that might be higher than the strict interpretation of accounting conceptual frameworks might give. Laeven and Majnoni (2003), Bikker and Metzemakers (2005) and Bouvatier and Lepetit (2008) provide consistent evidence that the lack of timeliness in loan-loss recognition under IL methods exacerbates economic downturns. These studies argue that IL methods prevent 
banks from timely loan-loss recognition in good times and require banks to increase loss allowances substantially in bad times, which hits regulatory capital when it is expensive to raise capital. Beatty and Liao (2011) predict that, in light of likely concerns about regulatorycapital constraints, banks with relatively untimely credit-loss recognition make relatively large reductions in their lending during recessions. Their results support this prediction. Bushman and Williams (2015) report that delayed loss recognition affects the stability of the banking system through the creation of codependence of downside tail risk among banks, with high-delay banks simultaneously facing in bad times financing frictions that will impede their access to new capital.

The directional effect of mechanisms that could be characterised as relating to pillar 2 'Supervisory Review Process' and pillar 3 'Market Discipline' on the preferences of prudential regulators with respect to loss allowances is less clear. In relation to loss allowances, these elements of the Basel framework contribute to the capital adequacy of banks by requiring that high-quality information should inform the determination of loss allowances and should be conveyed to market participants through those loss allowances. Relative to pillar-1-related channels, these channels might be more likely to induce a focus on faithful representation of losses, similar to that of accounting standard-setters, and might be less likely to motivate preferences for potentially overstated allowances. Ryan (2017) considers issues related to this matter. He argues that the effects of differences in methods of accounting for loan losses on regulatory capital ratios are likely to be relatively small: although loan-loss allowances may on average be a substantial proportion of equity (typically in the region of $10 \%$ ), they are on average a small proportion of total assets (typically in the region of $1 \%$ ). ${ }^{23}$ This suggests that regulatory-capital ratios, which express regulatory capital as a ratio of risk-weighted assets, are likely to be relatively insensitive to proportionate changes in loan-loss allowances. Based in part on such considerations, Ryan (2017) argues that, although there may be some effect 
through regulatory-capital ratios, the primary effect of banks' loan-loss-accounting requirements on financial stability is less likely to arise directly through the direct regulatorycapital-ratio channel than through the enhancement of the understanding of banks' risks on the part of the banks themselves, market participants and regulators. This argument suggests that accounting for loan losses may affect financial stability more strongly through channels related to the Basel pillars 2 and 3 than through the Basel pillar-1-related direct regulatorycapital-ratio-related channel.

Another mechanism by which the accounting for credit losses can influence stability is through its effect on banks' investing and funding decisions. As noted by Benston and Wall (2005) and Novotny-Farkas (2016), timely recognition of loan losses will reduce earnings and equity, which will themselves discourage risky behaviour with regard to investment and financing.

Although prudential regulators can be expected to share to some extent the preferences of accounting standard setters that loss allowances should faithfully represent losses and although regulatory-capital ratios may not be very sensitive to proportionate changes in loan-loss allowances, there is reason to believe that asymmetric loss functions in combination with direct effects of loss allowances on regulatory capital referred to earlier might give prudential regulators a lower aversion to over-stated loss allowance than accounting standard setters have.

\section{The development since 2009 of the FASB's and the IASB's expected-loss-based methods of accounting for credit-loss impairment}

In the aftermath of the financial and banking crisis of the late 2000s, the FASB and the IASB each proceeded with the development of credit-loss impairment methods aimed at achieving more timely recognition of predictable losses. ${ }^{24}$ In this section, we outline the development between 2009 and 2016 of the FASB's and IASB's EL methods for accounting for 
impairment relating to credit losses. We provide a summary and discussion for each of the sets of proposals issued by the standard setters. Our summaries and discussions are based on: (i) our review of FASB and IASB publications; (ii) our review of FASB and IASB meeting records and recordings of meetings; (iii) our confidential conversations with senior observers of the process; (iv) our reading of comment letters written in response to the five proposal documents issued by the FASB and/or the IASB between 2009 and 2013, of which discussion is informed by analysis reported in O'Hanlon et al. (2018).

A representation of the timeline of key outputs is presented in Figure 1, which gives full titles of the outputs. For fuller details of the proposal documents, see the European Parliament paper by O'Hanlon et al. (2015) and the related paper by Hashim et al. (2016). ${ }^{25}$

\subsection{IASB Exposure Draft: November 2009 (IASB 2009)}

IASB (2009) aimed to reflect the economics of lending. In particular, it aimed to avoid the problem whereby, under the pre-existing IL method, interest revenue was recognised in full from the origination of a loan but initially-expected losses that are compensated within the interest revenue were not recognised until loss events occur:

The (IL) approach is internally inconsistent because expected losses are implicit in the initial measurement of the asset, but not taken into account in determining the effective interest rate used for subsequent measurement. This results in a systematic overstatement of interest revenue in the periods before a loss event occurs. In effect, subsequent impairment losses are in part reversals of inappropriate revenue recognition in earlier periods. (IASB 2009, paragraph BC11)

The IASB (2009) method treated the transaction price (amount lent or purchase price) at which financial assets were initially recognised as being the present value of expected future cash inflows as at the initial-recognition date, net of future shortfalls relative to contractual cash flows (credit losses) expected as at that date, discounted at a credit-loss-inclusive integrated effective interest rate (hereinafter, IEIR). The IEIR would be used for accrual of interest revenue. Recognition of initially-expected credit losses would thereby be spread over 
the expected life of assets. Subsequent revisions to expected cash flows, discounted at the initially-estimated IEIR, would then be recognised in full as they occurred. Figure 2 represents this diagrammatically. Figure 3 includes a numerical illustration of the recognition of initially-expected credit losses under the IASB (2009) proposal. We and many observers with whom we spoke share the view expressed in the IASB's subsequent 2013 exposure draft that 'expected credit losses are most faithfully represented by the proposals in the 2009 ED. Those proposals reflected the economic link between the pricing of financial assets and the expected credit losses at initial recognition' (IASB 2013a, p. 10). Analysis of comment letters reported in O'Hanlon et al. (2018) indicates strong support for the general principle of spreading across time of the recognition of initially-expected credit losses. However, based on the IASB's own assessment of feedback referred to in IASB (2014a, paragraph BCIN.12), analysis of comment letters reported in O'Hanlon et al. (2018) and comments that the authors received from observers, it is evident that the IASB (2009) IEIR method was widely regarded as posing substantial challenges: it would be difficult for preparers to combine interest and credit-loss information; it would be difficult for users to interpret measures that combine interest and credit-loss information. Some comment letters also questioned whether assets are priced by reference to expected losses in the way implied by IASB (2009). Also, some respondents to IASB $(2009)^{26}$ and some observers with whom we spoke noted that the smooth recognition of initially-expected credit losses over time in IASB (2009) is inconsistent with the uneven manner in which losses arise over time.

In light of feedback on IASB (2009), the IASB then pursued a path aimed at achieving its objective 'to reflect initial expected credit losses as part of determining the effective interest rate' (FASB/IASB 2011a, paragraph IN5) through a method that was more practicable than that described in IASB (2009), including within its subsequent attempt to develop with the FASB a converged common solution. 


\subsection{FASB Exposure Draft: 26 May 2010 (FASB 2010a)}

As indicated in its title, the FASB (2010a) exposure draft had a wider scope than IASB (2009), with credit-loss impairment being one of various financial-instrument issues that were addressed. With regard to credit losses, FASB (2010a) proposed that an entity should recognise credit impairment in net income 'when it does not expect to collect all contractual amounts due for originated financial asset(s) and all amounts originally expected to be collected upon acquisition for purchased financial asset(s)' (FASB 2010a, paragraph 38). Significant features of the FASB (2010a) proposals were that losses would no longer need to be 'probable' in order to be recognised and that it should be assumed that economic conditions at the impairment-measurement date would remain unchanged for the remaining life of assets held. An implication of FASB (2010a) was the requirement for full recognition at day 1 (i.e., at the time of initial recognition) of all credit losses expected over the contractual life of financial assets held. This treatment, which could be seen as an extreme form of unconditional conservatism, became a controversial issue later in the process. Figure 3 includes a numerical illustration of recognition of day-1 loss and of why this might be seen as a problem. The FASB (2010a) proposals differed from the IASB (2009) proposals primarily in that, whereas the IASB proposals gave relatively high weight to income-recognition considerations, the FASB proposals gave relatively high weight to balance-sheet-focused allowance-adequacy considerations. ${ }^{27}$

The FASB (2010a) method had much in common with the Current Expected Credit Loss (CECL) method subsequently included in the later FASB (2016) Accounting Standards Update on credit losses in that it removed the 'probable' threshold for loss recognition and in that it required loss-allowances to reflect all contractual amounts not expected to be collected for the remaining life of an asset. Despite its similarity to the eventual CECL EL method, it 
was not at the time regarded by the FASB as an EL method. This was because, as stated in FASB (2010a, Paragraph BC175):

[...] it would not permit an entity to forecast future events or economic conditions in developing those estimates as would occur in an expected loss model;

and

Under an expected loss model, the Board understands that an entity would recognize a constant rate of credit impairments through the life of the financial asset based on expectations about losses on the date of acquisition or origination, with any changes from initial expected credit impairments recognized in the period of the change.

Although for the reasons given above the FASB did not see the FASB (2010a) method as an EL method, neither did it see it as an IL method. This was 'because recognition of credit impairment would not be based on any triggering event' (FASB 2010a, Paragraph BC174). Despite what the FASB said about EL and IL in relation to the FASB (2010a) method, some respondents to FASB (2010a) interpreted the method as EL and some interpreted it as IL.

Feedback on FASB (2010a) was largely supportive of dropping the requirement that losses should be 'probable' in order to be recognised and was largely unsupportive of the proposal that it should be assumed that economic conditions at the impairment-measurement date would remain unchanged for the remaining life of assets. In light of feedback on FASB (2010a), the FASB pursued a path aimed at achieving an objective 'to ensure that the allowance balance was sufficient to cover all estimated credit losses for the remaining life of an instrument' (FASB/IASB 2011a, paragraph IN6), including through its subsequent attempt with the IASB to develop a converged common solution.

\subsection{Joint FASB/IASB Supplementary Document: January 2011 (FASB/IASB 2011a)}

The joint FASB/IASB supplementary document presented an impairment method that the FASB and IASB believed would 'enable them to satisfy at least part of their individual 
objectives for impairment accounting while achieving a common solution to impairment' (FASB/IASB 2011a, paragraph IN3). Specifically, it was hoped that the supplementary document would satisfy at least part of the primary objective of the IASB 'to reflect initial expected credit losses as part of determining the effective interest rate' and at least part the FASB objective 'to ensure that the allowance balance was sufficient to cover all estimated credit losses for the remaining life of an instrument' (FASB/IASB 2011a, paragraphs IN5-7).

FASB/IASB (2011a) retained the FASB (2010a) elimination of the FASB's 'probable' threshold. Unlike IASB (2009), it proposed that initially-expected credit losses should be decoupled from the effective interest rate. Unlike IASB (2009) and FASB (2010a), it stated clearly that the information set to be used in estimating expected credit losses should include all available information including 'historical data, current economic conditions, and supportable forecasts of future events and economic conditions' (FASB/IASB 2011a, paragraph B5). The requirement to use an information set including supportable forecasts that is substantially broader than permitted by pre-existing IL methods was carried forward with similar wording into all subsequent FASB and IASB exposure drafts and standards on credit losses, together with the elimination of the FASB's 'probable' threshold. The standard setters' converged broadening of the information set permitted to be used for the purpose of recognising credit-loss impairment addresses an important element of the problem with the timeliness of the accounting for credit losses highlighted in the crisis.

Another key proposal in the supplementary document was that, for the purpose of accounting for credit losses, financial assets should be categorised into a 'good book' and a 'bad book'. At each reporting date, the impairment allowance would comprise:

- for assets for which it is appropriate to recognise expected credit losses over time (good book), the higher of: (i) time-proportional expected credit losses (TPA), addressing through spreading of loss recognition over time the IASB's preference to 
reflect the relationship between expected credit losses and pricing; ${ }^{28}$ and (ii) credit losses expected to occur within the foreseeable future period (at least twelve months) (FFP), addressing the FASB's focus on loss-allowance adequacy; TPA can be seen as a spreading approach, which does not involve day-1 losses, ${ }^{29}$ and FFP can be seen as an immediate-recognition approach, which does involve day-1 losses;

- for all other assets (bad book), the entire amount of expected credit losses.

Assets would be included in and transferred between the good-book and bad-book categories in accordance with an entity's internal risk-management practices.

The joint FASB/IASB supplementary document elicited substantial numbers of responses from U.S. respondents that could be assumed to be FASB constituents and nonU.S. respondents that could be assumed to be IASB constituents or potential constituents. This permitted direct comparison of responses for the two groups reported in O'Hanlon et al. (2018), for which some statistics are reproduced in Table $1 .^{30}$

\begin{tabular}{|c|c|c|c|c|}
\hline Proposed treatment & \multicolumn{2}{|c|}{ Positive comment } & \multicolumn{2}{|c|}{ Negative comment } \\
\hline \multirow{4}{*}{$\begin{array}{l}\text { Categorisation into good book and bad book } \\
\text { Good-book allowance: TPA } \\
\text { Good-book allowance: FFP }\end{array}$} & Non-U.S. & U.S. & Non-U.S. & U.S. \\
\hline & $82 \%$ & $34 \%$ & $10 \%$ & $43 \%$ \\
\hline & $70 \%$ & $18 \%$ & $19 \%$ & $64 \%$ \\
\hline & $32 \%$ & $49 \%$ & $52 \%$ & $35 \%$ \\
\hline
\end{tabular}

These statistics indicate differences between preferences of FASB and IASB constituents that might contribute to barriers to FASB/IASB convergence on accounting for credit losses. Non-U.S. respondents tended to favour good book/bad book categorisation consistent with a preference to recognise initially-expected losses on good-book assets over time, whereas U.S. respondents tended to oppose it. With regard to the good-book allowance, non-U.S. respondents tended to favour an income-statement-focused spreading approach (TPA), 
whereas U.S. respondents tended to favour a balance-sheet-focused immediate-recognition approach (FFP) that would require day-1 losses.

\subsection{Continued Work on Seeking Convergence: The Three-Bucket Approach}

After receiving feedback on FASB/IASB (2011a), the FASB and the IASB continued in 2011 and 2012 with joint deliberations aimed at developing a possible converged method of accounting for credit-loss impairment. Within these deliberations, the standard setters considered a so-called three-bucket approach (FASB/IASB 2011b) developed from the proposals in the supplementary document. Here, assets would be categorised into one of three buckets:

- Bucket 1: assets that had not been affected by observable events indicating a direct relationship to possible future default, for which there would be partial recognition of expected losses, where options considered included TPA and 12-month expected losses;

- Buckets 2 and 3: assets affected by events indicating a direct relationship to future default, with bucket 2 comprising groups of assets for which specific assets in danger of default had not been identified and bucket 3 comprising specific assets for which credit losses are expected to occur or have occurred, for which lifetime expected losses would be recognised.

During their deliberations, the FASB and the IASB eliminated the TPA spreading approach from consideration. They agreed to deliberate a relative method in which all in-scope financial assets would initially be placed in bucket 1 , for which the allowance at each date including day 1 would comprise 12-month expected loss, with any assets that suffered significant subsequent deterioration in credit quality relative to credit quality at initial recognition then being moved to lifetime expected loss. In that it involved recognition of 12- 
month expected losses for bucket-1 assets, this method was similar to the FASB's preferred FFP good-book method and did not explicitly involve spreading in the way that the IASB (2009) IEIR method or the TPA method did. However, the IASB accepted this method, with some conceptual misgivings with regard to day-1 losses, in part because it offered a practicable approximation to the outcomes from the IASB (2009) IEIR method and in part because it was hoped that this might facilitate FASB/IASB convergence. ${ }^{31}$

In August 2012, the FASB indicated that it did not wish to continue to work with the IASB towards development of a method based on the three-bucket categorisation of financial assets into a non-credit-deteriorated category and a credit-deteriorated category with only partial recognition of expected credit losses for the first category, which it termed a 'dualmeasurement' approach. After the FASB's August 2012 decision, the FASB and the IASB proceeded to develop their own separate standards while continuing to consult with each other. In subsequent explanation in FASB (2012, paragraph BC11) of its decision to disengage from the three-bucket deliberations with the IASB, the FASB said that application of two different measurement objectives would be confusing for users, would involve a 'cliff effect' as assets were reclassified, would create earnings-management opportunities, and could be seen as involving an undesirable IL-type recognition trigger. Although we are not aware of evidence of a direct connection between the two events, we note that the August 2012 FASB meeting occurred only a few weeks after the publication of an SEC document (SEC 2012) that was viewed by the IASB Chair Hans Hoogervorst as signalling the end of the era of IASB/FASB convergence (McEnroe and Sullivan 2014, p. 18). ${ }^{32}$

The difference between the pre-existing practices of banks in the U.S. and elsewhere with regard to loss-allowances, which would contribute to the eventual failure of the FASB and IASB to achieve a common solution to accounting for credit losses, had been reflected in discussion at a joint FASB/IASB meeting in July $2011 .{ }^{33}$ At that meeting, there was both 
concern from the IASB side that recognition of a 12-month good-book (bucket-1) allowance at initial recognition was excessive and concern from the FASB side that a 12-month goodbook allowance was insufficient. At that meeting an IASB member questioned how a day-1 loss on assets originated at fair value could provide useful information to users of financial statements. A FASB representative indicated that the FASB might not wish to adopt a method for accounting for credit losses that reduced allowances: 'I start with the belief that there has to be some change here. Reserves generally have been inadequate in the U.S. banking system'. He said that he had conducted analysis that indicated that a 12-month bucket-1 allowance would have virtually no impact on loss allowances of U.S. commercial banks and might even reduce them. In response, an IASB representative noted that this was a U.S.-bank perspective and would not be expected to hold outside the U.S.

Further illustration of the tensions caused by the differences in pre-existing practice with regard to allowances that had contributed to the failure of the FASB and the IASB to agree a common three-bucket-based solution is given by discussion at an IASB meeting of October $2012 .^{34}$ Here reference to allowance levels is linked to concerns of bank regulators. At that meeting, an IASB member referred to the following passage in an IASB feedbacksummary paper and requested further information from the IASB staff about the issue referred to: $:^{35}$

The prudential regulators have not expressed a formal opinion on the three-bucket model at this stage. However, their preliminary feedback was mixed. Some, particularly in the U.S., favour a lifetime expected loss model. This is primarily because they fear that the three-bucket approach may actually reduce allowance balances relative to those recognised today. Some were concerned that the three-bucket model, unless more clearly articulated, could enable entities to avoid recognising lifetime expected losses on a timely basis.

An IASB staff member said that this paragraph reflected U.S. bank regulators' concern that, because of the way in which U.S. banks used IBNR-type loss provisioning in their current application of SFAS 5 (FASB 1975), the application of a three-bucket method in the U.S. 
might result in a reduction of allowance balances relative to their then-current levels. Another IASB staff member then commented as follows:

That's very U.S.-specific. The feedback we have had from our constituents outside the U.S. is that, based on their analysis of the model [....], there would be an increase in provisions based on the three-bucket model and, in some cases, a very significant increase in provisions. And that is one of the tensions [...] that we have had all the way through this project in that the starting places of the banks in different parts of the world are so different. This puts a lot of pressure on our ability to come to a converged solution.

We note that the concerns of bank regulators referred to above are consistent with the direction that might be predicted based on our discussion in subsection 2.3.2.2.

Allowance-adequacy-related concerns of the FASB with regard the three-bucket proposals were also reflected by a FASB representative at a joint FASB/IASB meeting in July 2013: it had been estimated that the three-bucket approach favoured by the IASB would reduce U.S. allowances by about $15 \%$ whereas the FASB preferred 'single-measurement' approach, under which full-contractual-life expected credit losses would be recognised, would increase them by about $40 \% .^{36}$

From the above, it can be seen that, by the later stages of the process, the seriousness of the challenge posed by the difference between pre-existing practice with regard to lossallowances in the U.S. and elsewhere was well recognised. Related to this, it is notable that the FASB and U.S. prudential regulators tended to see pre-existing U.S. GAAP as giving rise to insufficiently timely recognition of credit losses and inadequate loss allowances, ${ }^{37}$ and feared that the measures that were proposed by the IASB to improve matters in this regard might make matters worse in the U.S.

We did not note evidence from meeting records that differences between the IASB and the FASB with respect to pre-existing accounting standards or with respect to conceptual reasoning were a major source of the FASB/IASB differences. In relation to this, the FASB and IASB had issued in 2010 identical conceptual framework chapters entitled 'Qualitative 
characteristics of useful financial information', which referred to matters including 'bias' and 'neutrality' that are highly relevant to this issue (FASB 2010b, IASB 2010). Furthermore, as noted below, an IASB member in the final IASB exposure draft (IASB 2013a) and two FASB members in the final FASB standard (FASB 2016) raised very similar conceptually-based objections to day-1 losses later in the process.

\subsection{IASB Exposure Draft: March 2013 (IASB 2013a) and IFRS 9: July 2014 (IASB 2014a)}

The IASB decided at a December 2012 meeting to issue a new exposure draft incorporating a three-bucket approach. This was subsequently issued in March 2013 (IASB 2013a). ${ }^{38}$ Discussion at the December 2012 meeting indicated that a major cause of the IASB's objection to the FASB's preferred method was its understanding of the likely magnitude of the FASB's lifetime day-1 losses, which were expected to be substantially larger than the IASB's 12-month day-1 losses. The following comment from the Chair of the IASB at the December 2012 meeting illustrates that IASB members acknowledged the conceptual flaw with the 12-month allowance and associated day-1-loss, and that this feature had initially been accepted by the IASB in part because it might have assisted with convergence with the FASB which was no longer expected to occur as part of the then-current process: ${ }^{39}$

[...] I do recollect that the whole board had a severe hiccup about this 12-month day-1 loss. We didn't like it because it is conceptually flawed, and we know that, but we were willing to [...] take that, first of all because we were in the process of reaching some kind of convergence with the FASB. Well, that moment has unfortunately passed, but we were where we were and it was not very simple to come up with a simple and better solution for this issue [...] There are conceptual issues. Fortunately, quantitatively our conceptual flaw is a lot smaller than $[\ldots]$ the current FASB proposal [...].

Despite the conceptual concerns with the 12-month day-1 allowance, there did not appear to be any appetite at that stage to re-open consideration of other approaches that would have delayed progress towards the issue of a final standard, and IASB (2013a) was issued on the basis that it was likely to result in the approximate achievement of the aim of IASB (2009) to 
recognise initially-expected credit losses over time. Assets were described as being in one of three 'stages' with regard to credit deterioration, where stages 1, 2 and 3 corresponded closely to buckets 1, 2, and 3 from the three-bucket proposals. The stages are as follows:

- Stage 1 assets: assets for which credit quality has not deteriorated significantly since initial recognition or that have low credit risk at the reporting date. 12-month expected losses are recognised, including at day 1 , and interest is calculated based on the gross carrying amount before deducting the loss allowance; ${ }^{40}$

- Stage 2 assets: assets for which credit quality has deteriorated significantly since initial recognition, unless they have low credit risk at the reporting date, but for which there is no objective evidence of a credit-loss event. Full lifetime expected credit losses are recognised, with interest calculated on the gross carrying amount before deducting the loss allowance;

- Stage 3 assets: assets for which there is objective evidence of impairment. Full lifetime expected credit losses are recognised, with interest calculated on the carrying amount of the asset after deducting the loss allowance.

One board member's concern about the 12-month allowance with its day-1 loss requirement for stage-1 assets was expressed as follows within an alternative view published within IASB (2013a):

the loss allowance at an amount equal to 12-month expected credit losses would result in a credit loss at initial recognition even when a financial asset is priced on market terms and where, consequently, no economic credit loss exists [...] In no other area of financial reporting is an allowance immediately established to reduce the value of an asset that is purchased or originated on market terms. (IASB 2013a, paragraph AV2)

As reported in O'Hanlon et al. (2018), non-U.S. responses to IASB (2013a) included a substantial amount of negative comment on the day-1-loss requirement, much of which referenced supportively the alternative view published within the exposure draft. There was also some concern about operational practicability of the transfer criterion from the 12- 
month-loss category to the lifetime-loss category. However a substantial majority of respondents regarded the 12-month loss allowance for stage-1 assets together with transfer to lifetime loss after significant-deterioration in credit quality as an acceptable approach. At an IASB meeting of September 2013, an IASB member noted the apparent contradiction in the fact that a large number of respondents to IASB (2013a) had said that the 12-month allowance was both conceptually unjustified and acceptable. ${ }^{41}$

IFRS 9 (IASB 2014a) incorporated the key proposals of IASB (2013a), including the three stages and the 12-month loss allowance (including at day 1 ) for stage- 1 assets. $^{42}$ It noted that the recognition of 12-month expected losses for assets for which credit risk has not increased significantly since initial recognition was a cost-benefit-based operational simplification for dealing with expected losses on good-book assets (IASB 2014a, paragraph BC5.195). It included a requirement that measurement of expected credit losses should reflect a broadened information set that includes 'reasonable and supportable information that is available without undue cost or effort at the reporting date about past events, current conditions and forecasts of future economic conditions' (IASB 2014a, paragraph 5.5.17). No dissenting opinion on the 12-month allowance and its day-1 loss was included in IFRS 9 (IASB 2014a).

It remains to be seen whether day-1-loss becomes a significant problem in years after IASB (2014a) has become effective.

\subsection{FASB Exposure Draft: December 2012 (FASB 2012) and FASB Accounting Standards Update No. 2016-13: June 2016 (FASB 2016)}

The FASB (2012) exposure draft was issued in December 2012. It proposed 'only one measurement approach, which is the current estimate of contractual cash flows not expected to be collected on financial assets held at the reporting date' (FASB 2012, p. 5). FASB (2012) was developed into the Accounting Standards Update (FASB 2016) containing the CECL 
method. This requires that the allowance for expected credit losses is 'a valuation account that is deducted from the amortised cost basis of the financial asset(s) to present the net amount expected to be collected on the financial asset' (FASB 2016, paragraph 326-20-30-1). FASB (2016) included a requirement that measurement of expected credit losses should reflect a broadened information set: 'an entity shall consider available information relevant to assessing the collectibility of cash flows. This information may include internal information, external information, or a combination of both relating to past events, current conditions, and reasonable and supportable forecasts' (FASB 2016, paragraph 326-20-30-7).

Difficulties in achieving a shared understanding between the FASB and financialstatement preparers with regard to what is required by CECL appeared to contribute to the substantial time that elapsed between FASB (2012) and FASB (2016). As reported in O'Hanlon et al. (2018), responses to FASB (2012) indicate that a high proportion of U.S. respondents had concerns about the practicability of estimation and interpretability of allowances covering expected losses over the whole life of assets and with regard to the requirement to recognise such allowances at day 1 . In response to feedback reflecting concern about the difficulty of estimating expected losses over the whole contractual life of assets, the FASB acknowledged that it may not have explained the CECL forecasting requirements very well in FASB (2012), ${ }^{43}$ and it took steps to allay concern about these. It emphasised in its final standard that:

for periods beyond which the entity is able to make or obtain reasonable and supportable forecasts of expected credit losses, an entity shall revert to historical loss information. (FASB 2016, paragraph 326-20-30-9) ${ }^{44}$

The day-1-loss feature became a focus of a dissenting opinion by two FASB members. They referred to the belief of some commentators that:

the incremental loss that would be recognized [...] is not based on the economics of the transaction but rather on a prudential desire to have a higher level of loan loss reserves reflected in financial reports to investors. (FASB 2016, pp. 236-237) 
Using similar language to that of the IASB (2013a) alternative view, they questioned the conceptual soundness of day-1 loss:

They are unaware of any other area of financial reporting for which a loss and a related valuation allowance are immediately established to reduce the value of a recognized asset that is purchased or originated on market terms. (FASB 2016, p. 237)

It remains to be seen what problems may arise after FASB (2016) has become effective in relation to the requirement to estimate expected losses over the whole life of financial assets held and the requirement to recognise such expected losses in full at day 1.

\subsection{Involvement of regulators in the process}

Subsection 2.1.4 refers to preferences from regulatory-related sources for the development of accounting standards that would give more timely recognition of credit losses. It is useful at this point to comment on the involvement of regulators in the process described in this section. It is evident from our examination of meeting records that financial and banking regulators were consulted throughout the process. ${ }^{45}$ As might be expected based on our review in subsection 2.3.2.2 of issues related to timely recognition of losses and the stability of the financial system, regulators tended to prefer relatively conservative approaches. This is exemplified by the reference in subsection 3.4 above to regulators' concern that three-bucketbased allowances might be inadequate. It is also exemplified by a similar concern on the part of prudential regulators reflected in an IASB outreach summary in respect of IASB (2013a). ${ }^{46}$ Financial and banking regulators submitted comment letters in respect of all five proposal documents referred to above. ${ }^{47}$ In the relatively small number of letters from financial and banking regulators in response to FASB (2012) and IASB (2013a) examined by O'Hanlon et al. (2018), there was substantially less opposition to day-1 loss than from other respondents. ${ }^{48}$ 


\section{Problems that may arise when the standards become effective: lifetime losses and day-1 losses}

The standard setters have moved relatively straightforwardly to a converged broadening of the information set that is permitted to be used in estimating credit losses that can be recognised in financial statements. Instead of the relatively restricted information set permitted by pre-existing IL methods, both standard setters permit the use of an information set that, without the pre-existing FASB 'probable' threshold, includes reasonable and supportable forecasts (IASB 2014a paragraph 5.5.17, FASB 2016 paragraph 326-20-30-7). This directly addresses a major element of the problem with the lack of timeliness in creditloss recognition that gave rise to concern in the wake of the financial and banking crisis of the late 2000s. However, this very positive outcome was achieved within a lengthy process that also resulted in what some regard as less desirable outcomes. O'Hanlon et al. (2018) report that comment letters written in response to the standard setters' final exposure drafts suggest two particular issues that may give rise to problems when the standards become effective.

First, the FASB's requirement that loss allowances at each date should recognise all credit losses expected to occur over the whole life of assets gave rise to a high level of concern, in particular with regard to practicability of implementation. An illustration of this type of concern was provided at a FASB roundtable meeting of 4 February 2016. At that meeting, Community Bank representatives expressed strong concern arising from their understanding that the FASB's requirement within the CECL method for estimation of expected losses over the whole life of assets would require them to use complex and costly models that would be of no incremental value within their businesses. As noted above, the FASB has made substantial effort to address the causes of such concern.

Recent literature includes some suggestion that the requirement to recognise fullcontractual-life expected losses in a U.S. context may not be as big a problem as it might first 
appear and may have a beneficial effect. Wu (2016) argues that the level of sales, prepayments and defaults in the U.S. context may mean that the time that loans are expected to remain within lenders' loan books may be substantially shorter than their full contractual life. Although this does not eliminate the requirement to estimate losses over the full contractual life of loans, ${ }^{49}$ it may mean that the task of forecasting such losses is facilitated by the ability to assume that losses beyond a certain point will be minimal. Giner and Mora (2018) argue that a requirement to recognise full-contractual-life expected losses could be beneficial in the U.S. context, in which the originate-to-distribute business model is relatively common. Such a requirement might be expected to achieve the timely recognition of credit losses that are expected to arise years after disposal/distribution and that might not be recognised in a timely manner before disposal/distribution under the IASB's 12-month expected-loss approach. Giner and Mora (2018) argue that the requirement may consequently have the beneficial effect in the U.S. context of discouraging excessively risky lending.

Second, both standard setters have introduced requirements to recognise at day 1 initially-expected losses on assets originated or acquired at fair value. ${ }^{50}$ The problem with day-1 loss is illustrated in Figure 3, referred to previously. There are various ways in which this problem can be expressed. Examples are listed below with, in each case, an endnote reference to a comment letter expressing the problem in that way:

1. Writing an asset down to below fair value immediately on initial recognition appears to be inconsistent with the standard setters' conceptual frameworks which require faithful representation of the phenomena that are purported to be represented. ${ }^{51,52}$

2. In that they are reflected both in the numerator and the denominator of a discountedcash-flow (DCF) calculation, initially-expected losses are counted twice. See Figure 3. This is similar to the error that might arise if one were to discount a risk-adjusted stream of expected future payoffs using a risk-inclusive discount rate. ${ }^{53,54}$ 
3. Assuming that the pre-day-1-loss book value of an originated asset is equal to fair value at the origination date, this book value already recognises origination-date expectations regarding the amount and timing of shortfalls relative to contractual cash flows. These expectations should not be recognised again at the origination date. ${ }^{55}$

4. Recognising credit losses at origination but recognising associated credit-premiuminclusive interest later does not reflect the economics of the lending transaction. ${ }^{56}$

5. The requirement to write risky loans down to below fair value at the origination date suggests possibilities for earnings management, for example by originating a portfolio of risky loans in one period (in which a day-1 loss would be recognised) in the expectation of disposing of it at fair value in a subsequent period (in which the day-1 loss would be reversed). ${ }^{57}$ See subsection 2.3 .1 for evidence that banks have used credit losses to manage earnings where opportunities arose.

Furthermore, it was noted as part of the standard-setting process, including in the FASB's summary of feedback on FASB (2012), that day-1 loss may have the adverse economic effect of disincentivising lending. ${ }^{58}$

The standard setters' introduction of the requirement to recognise credit losses at day 1 could be seen as a form of unconditional conservatism, which as noted in subsection 2.3.2.1 can have the adverse effect of restricting the extent to which informationally-valuable newsdependent conditional conservatism can be applied. Compared with other unconditionally conservative treatments, recognition of initially-expected losses at day 1 could be seen as relatively extreme. It appears similar to the application of an extreme form of accelerated depreciation under which all of the depreciation expected to be recognised over the life of an asset is recognised immediately on acquisition.

Although there is a widespread view that the recognition of day-1 losses is not conceptually justified, a number of U.S.-based observers with whom we discussed this issue 
suggested that recognition of day-1 loss can give reasonable outcomes. Rationales for this view included the following. These rationales were also reflected either in comment letters, to which we provide an endnote reference to an example in each case, or in the academic literature:

1. Losses tend to occur early in the life of a loan. ${ }^{59}$ Although they do not typically occur at day 1, day-1 recognition is consistent to some extent with the early incidence of losses. Concerns about whether day 1 or some other time is the right time to recognise losses may sometimes derive from unrealistic beliefs about the accuracy with which the timing of losses can be predicted. This argument holds particularly in the case of large open portfolios.

2. Once a bank makes a loan, it takes on the exposure to the risk of losses inherent in the loan. In the interests of having an appropriately prudently-stated balance sheet at the possible cost of a less informative income statement, it is desirable to recognise losses at the outset. ${ }^{60}$ This argument is related to the following argument made by the FASB in its justification of the recognition of losses at origination within a response to a 'frequently asked question': ${ }^{61}$

When an entity originates a loan, that entity has increased its exposure to credit losses. Likewise, when a contractual payment is received in full from the borrower, the entity's exposure to credit loss has decreased. The Board believes that recognizing all expected credit losses in the balance sheet causes the income statement to appropriately reflect the economic phenomenon that has occurred namely, the extent to which an entity has increased or decreased its exposure to credit risk during the period.

3. Related to the previous point, with imperfect information and in particular in good economic times, amounts lent may exceed the fair value of the expected future cash receipts from the loan. A limited element of day-1 loss may help deal with this. This argument has some similarity to an argument by a U.S. bank regulator from the 1990s referred to by Wall and Koch (2000, p. 9): bad loans tend to be made in good times, and 
it is therefore appropriate to establish loss allowances in good times in order to cover the as-yet-unidentified losses that will subsequently be revealed.

Concern about day-1 loss is raised primarily with reference to the FASB's CECL method, for which expected losses over the full contractual term of financial assets have to be recognised at day 1. The issue also arises with IFRS 9 (IASB 2014a). However, it is important to note that the FASB's rationale for including a day-1 loss allowance was different from that of the IASB. The 'frequently asked question' response quoted above suggests that the FASB believed that reflecting initially-expected losses at day 1, which is easily justified for the purpose of determining banks' capital requirements, is also the conceptually correct thing to do for the purpose of measuring credit-loss expense and loss allowances in financial statements. In contrast, it appears that IASB's introduction of a day-1-loss requirement was not based on a belief that recognition of day-1 loss was conceptually correct. As noted earlier in our subsection 3.5, the IASB's day-1-loss requirement appears to have been introduced because it was believed to provide a practicable approximation to the recognition of initiallyexpected losses over the life of financial assets and because, at the time at which the IASB had initially decided to accept this approach, it was believed that this might facilitate FASB/IASB convergence.

Overall, it appears difficult to justify day-1 loss on conceptual grounds. One possible justification is that it provides a practicable approximation to the outcomes from a conceptually more justifiable spreading-based approach. Another might be conservatism. However, as indicated above, day-1 loss is an example of unconditional conservatism, which it can be argued creates uninformative bias. 


\section{Was expected-loss the best route to improvement of accounting for credit losses?}

Evidence of the perceived major nature of the change involved in introducing an EL method can be found in the statement in a letter of 13 January 2016 to the FASB Chair from the President and CEO of the ABA that 'The CECL model represents the biggest change - ever to bank accounting. ${ }^{62}$

As we have noted above, a notable achievement of the two standard setters was their converged broadening of the information set used to measure credit-loss impairment, such that it includes reasonable and supportable forecasts and is not subject to a 'probable' threshold. Subject to caveats about opportunities that this might create for earnings and capital management, on which prior evidence was reviewed in subsection 2.3.1, this should have a significant beneficial effect with respect to timeliness in the accounting recognition of information about credit losses, which was a major focus of criticism in the aftermath of the

financial and banking crisis of the late 2000s. ${ }^{63}$ In this subsection, we raise the question of whether the improvement in the timeliness of credit-loss recognition, including through broadening of the information set permitted to be used, could have been achieved more straightforwardly and in a more converged manner through an alternative route to the type of EL route that the standard setters followed.

\subsection{Is there a clearly understood distinction between incurred loss and expected loss?}

Our study of events since 2009 leads us to the view, similar to that reflected in the study by Camfferman (2015) to which we referred previously, that there appears not to be a clear and widely-shared understanding of the distinguishing features of an EL method relative to an IL method in relation to accounting for credit losses. Observations that contribute to this view are as follows: 
1. As noted in subsection 3.4 above, FASB documents reported the claim that the principle within the three-bucket EL method for determining whether an asset should be moved to the lifetime-loss category could be seen as introducing an IL trigger. Although some observers with whom we spoke feel that this claim is unfair, it illustrates the potential difficulty in distinguishing between IL methods and EL methods.

2. Some respondents to FASB (2010a) saw the FASB (2010a) method as an EL method, some respondents saw it as an IL method and, as noted in our subsection 3.2, the FASB itself saw it as neither.

3. The rationales for the FASB (2010a) impairment method not being seen by the FASB at the time as an EL method included that it would not spread recognition of initiallyexpected losses over time. However, such a feature was also absent from the FASB's own final EL (CECL) method in FASB (2016), which dealt with expected losses through full recognition at each reporting date without any spreading procedure.

4. At the FASB roundtable meeting of 4 February 2016, a Community Bank representative described what he saw as an acceptable more forward-looking adaptation ('tweak') of the pre-existing IL method. FASB representatives commented that the process described by the Community Bank representative was an example of an implementation of the CECL EL method.

Drawing on the above and our reading of comment letters, we have observed a number of views with regard to the distinguishing feature of an EL method relative to an IL method. Some understand that a distinguishing feature of EL is simply that impairment is based on expected cash flows or expected losses. Some understand that a distinguishing feature is that impairment is based on expected cash flows and expected losses where expectations are derived from an information set that can include forecasts of future events and economic conditions. Some understand that a distinguishing feature is that recognition of initially- 
expected losses is spread over the life of assets. The observation that the term 'expected loss' can mean different things to different people was also noted in a FASB summary of feedback on FASB (2012). ${ }^{64}$

\subsection{Preferences for a route other than expected loss}

Examination of comment letters on the standard setters' various proposal documents since 2009 indicates that some prominent respondents have continued to express a preference for the retention of an IL approach, typically in a modified form with a broadening of the information set that might be used as a basis for recognition of credit-loss impairment. For example, the Association of Chartered Certified Accountants (ACCA), which is one of the UK's major accounting bodies, said in its comment letter in response to IASB (2013a) that: ${ }^{65}$

ACCA would prefer to retain the current incurred loss model which is less subjective and does contain a clear principle that can be applied across the piece. An incurred loss model in the new IFRS 9 however should be modified from the present IAS 39 version, by making it clear that losses that have been incurred but have not yet been reported as defaults should be recognised and that losses can occur before debtors actually default on repayments.

Also, the ABA has provided detailed comment along similar lines. In its comment letter of 14 May 2013 on the FASB (2012) exposure draft, the ABA said that, among other things, CECL will: 'require enormous and costly operational change, and potentially wreak havoc with FASB's own conceptual framework of accounting'. The ABA then went on to state its preference for a proposed modified IL model termed the Banking Industry Model (BIM): ${ }^{66}$

The BIM (initially introduced in 2011) is the best path toward an internationally converged solution that responds to concerns of bankers, bank investors, and banking regulators by:

- Discontinuing the "probable loss" notion.

- Providing appropriate guidance in understanding the loan impairment process, "loss events," and "forward-looking loss events," as well as additional disclosures to assist users in understanding the processes and comparing them between companies.

- Recognizing subliminal risks that build during an economic expansion in a transparent fashion. 
- Retaining impairment accounting within the FASB conceptual framework by recognizing impairment only when a loss event is believed to have occurred.

- Building on current systems and financial metrics, rather than wholesale change.

The BIM referred to above had previously been described in an appendix to the ABA's comment letter of 11 March 2011 in response to the 2011 supplementary document. The ABA introduced its BIM as follows: ${ }^{67}$

We believe that the fundamental principles inherent in the incurred loss model are sound and have served the industry, regulators and financial statement users effectively by providing a well understood framework to determine credit-related allowances. However, over time, the incurred loss model has increasingly been interpreted in a way that has resulted in a significant flaw: allowance calculations based on too narrow a view of the credit cycle. History has shown that the credit profile of financial instruments is highly cyclical, typically with a period of benign loss activity that coincides with the expansion and peak of overall economic activity and credit availability, followed by a shorter and more concentrated period of elevated credit losses. Narrow interpretations and application of the incurred loss model result in the compression of this cycle by considering only losses estimated over an abbreviated loss emergence period and restricting the use of market trends and other data that would indicate changes in the probability or severity of loss until such deterioration is observable. The events of the recent financial crisis put a spotlight on this weakness in the application of the incurred loss model, resulting in the criticism noted above. Although we believe the fundamental principles of the incurred loss model remain sound, some thoughtful and tailored changes are necessary to incorporate the cyclical behavior of financial instruments and lack of transparency around inherent losses prior to the deterioration of the credit environment.

The BIM is then described as comprising two components:

(1) A base component (the "Base Component") that represents the estimate of expected inherent losses in the portfolio that are reasonably predictable;

(2) A credit risk adjustment component (the "CRA") that represents additional credit losses that are not yet reflected in current credit risk metrics used to estimate the Base Component but are estimated using macro-level factors and are expected to emerge with more transparency as the credit cycle unfolds.'

The second item is similar to items denoted 'incurred but not reported' in IAS 39 (IASB 2003, paragraph AG90). The preference referred to above for a broader application of the IL method is echoed in comment letters on FASB (2012) and IASB (2013a) examined by 
O'Hanlon et al. (2018). ${ }^{68}$ The claim that the IL method was being applied in an insufficiently conservative manner prior to the crisis is reminiscent of the point that was made in SFAS 114 (FASB 1993a, paragraph 10) and quoted in our subsection 2.1.1 about the desirability of avoiding insufficiently conservative application of SFAS 5 (FASB 1975).

\subsection{An alternative way of approaching the improvement of accounting for credit losses?}

In this subsection, we raise the question of whether the EL route was the best route to follow for the purpose of improving the accounting for credit losses.

We first offer our own view of how the terms 'incurred' and 'expected' might relate to each other in the context of accounting for credit losses:

i. Any method of accounting for credit losses must use a current (as at the lossrecognition date) information set of some sort;

ii. Any method of accounting for credit losses operates in a setting in which financial assets were originally recognised at a transaction price (amount lent or purchase price) that can normally be expected to have reflected expectations at the initial-recognition date of future shortfalls relative to contractual cash inflows;

iii. The information set referred to in (i) is used, explicitly or implicitly, to make estimates of expected future cash flows (or shortfalls relative to contractual or previously expected amounts) and risk in relation to a financial asset or financial assets;

iv. These estimates are used, explicitly or implicitly, to arrive at an appropriate carrying value for a financial asset or financial assets;

v. The appropriate carrying value is then compared with the pre-existing carrying value of the asset or assets to establish what loss if any has been incurred and should be recognised as an impairment within a loss allowance. 
In this representation, in which the terms 'expected' and 'incurred' both appear, IL/EL is not a key distinguishing feature. We believe that more meaningful distinguishing features are as follows:

1. (In item (i)) The information set that is permitted to be used. This could be a restricted information set comprising events and evidence of the sort permitted within pre-existing so-called IL methods, for which the link to estimates is relatively direct and provides relatively precise estimates of impairment. Alternatively, it could be a broader information set comprising events and evidence of the sort permitted within pre-existing so-called IL methods plus reasonable and supportable impairment-measurement-date forecasts of subsequent events and economic conditions, for which the link to estimates is relatively less direct and may provide estimates of impairment that are relatively less precise and that are relatively vulnerable to earnings management.

2. (In item (ii)) The treatment of initially-expected shortfalls relative to contractual cash inflows. The initial carrying value of any financial asset (amount lent or purchase price) will reflect expectations at the initial-recognition date of future shortfalls relative to contractual cash inflows. All impairment methods, whether they are described as IL or EL or anything else, have to deal in some way with such initially-expected shortfalls (initially-expected losses). One possible approach to dealing with this issue would be to recognise the initially-expected shortfalls at the time of the initial recognition of the asset. A second possible approach would be to spread the initially-expected shortfalls across the life of the asset alongside the accrual of interest. Both of these approaches have been proposed within EL methods in recent years. The first was adopted within FASB (2016) and, for a subset of the initially-expected shortfalls, in IASB (2014a). However, although it may be consistent with the way in which bank regulators require expected losses on exposures to be reflected for the purpose of determining banks' 
capital requirements, this approach is not easily justified for the purpose of measuring credit-loss expense and loss allowances in financial statements. The second was proposed in IASB (2009) but was not adopted, mainly due to claimed implementation problems. A third possible approach, which is the traditional approach adopted within IL methods, is to recognise such initially-expected shortfalls during the life of the assets, alongside shortfalls that were not initially expected, as part of impairments triggered when specified conditions, such as the occurrence of 'loss events', are met. The problem with this third approach, as was noted in motivating the IASB (2009) IEIR-based proposal (IASB 2009, paragraph BC11), is that the restrictive nature of the specified conditions might result in credit-premium-inclusive interest revenue being recognised in advance of the associated initially-expected shortfalls.

The problem with IL methods referred to above brings us back to the information set that is permitted to be used as the basis for the accounting recognition of credit losses. A broadening of the information set within an IL framework, to include reasonable and supportable forecasts of future events and economic conditions and with fuller use of the preexisting 'incurred but not reported' concept, might have addressed both the need for new information on credit losses to be recognised in a more timely manner and the need for initially-expected losses to be recognised significantly earlier than under pre-existing practice. A broadening of the information set within an IL framework could reasonably be expected to reduce substantially the mismatch between the timing of the recognition of initially-expected losses and the recognition of associated credit-premium-inclusive interest revenue that the IASB (2009) spreading approach was aimed at addressing. Such a route would present accounting standard setters with a challenge in balancing the desirability of a broader and more forward-looking permitted information set against the desirability of restriction on earnings management. However, such a challenge also exists with the EL 
methods that have been developed. Also, as illustrated in subsection 2.3.1, earnings management by banks is an extensively researched issue and is likely to be familiar territory for accounting standard setters and accountants.

At least, such an approach would have avoided conceptually-questionable day-1-loss which, because the FASB and IASB could not agree on the degree of conservatism to be applied in recognising losses at day 1, was an important contributor to the failure of the FASB and the IASB to achieve convergence on accounting for credit losses.

It is helpful to consider now what might have been the main contributory factor to the requirements for day-1 losses in the final FASB and IASB standards. The fact that IASB (2009) was issued in the immediate aftermath of the crisis and proposed an EL method without day-1 losses suggests that neither political and regulatory pressure for increased loss allowances in the immediate aftermath of the crisis nor the choice of an EL route itself was a main contributory factor. We believe that the main contributory factor was the choice to adopt the particular type of EL approach that was eventually adopted. We make the following distinction between EL approaches:

1. Spreading-based approaches. Methods that aim to achieve the suitably timely recognition over time of initially-expected losses, for example through the IASB (2009) IEIR method or the FASB/IASB (2011a) TPA method, plus immediate recognition of changes in expectations about expected losses.

2. Immediate-recognition-based approaches. Methods that aim to achieve the recognition at each reporting date of expected future losses. This category includes the FASB (2016) CECL method. The IASB (2014a) method also falls into this category, although its use of a 12-month good-book loss allowance is aimed at approximating the distribution of income across time that would occur under spreading-based approaches. 
A key difference between the two categories is that the first does not give rise to day-1 losses but the second does. The key factor leading to day-1 losses appears to have been the choice, after spreading-based EL approaches had been eliminated from consideration during the three-bucket deliberations, to follow immediate-recognition-based EL approaches of the type that prudential regulators might be comfortable with. As observed above, an alternative path that could have been taken at this point was exploration of broader-information-set-based and more-responsive IL-type approaches that could have approximated the outcomes of an EL spreading approach without leading to day-1 losses.

\section{Conclusion}

In the wake of the financial and banking crisis of the late 2000s, the FASB and the IASB moved quickly to improve the timeliness of the accounting recognition of credit losses, including through an attempt to reach a converged common solution. With regard to accounting for credit losses, the crisis appeared to have prompted a shift in relative concern away from the need to constrain earnings management and towards the need to facilitate timeliness of loss recognition and loss-allowance adequacy. With the encouragement of the Financial Stability Board (2009), BCBS (2009) and the Financial Crisis Advisory Group (2009), the accounting standard setters followed a route based on the concept of EL, which in relation to credit losses had originally become prominent for the purpose of setting banks' capital requirements. Following the EL route, the standard setters arrived relatively straightforwardly at a converged broadening of the information set to be used for the purpose of estimating credit losses to be recognised in financial statements, such that it would include reasonable and supportable forecasts. We believe that this directly addresses to a significant degree problems with the timeliness of the accounting for credit losses that were highlighted in the crisis. However, the standard setters encountered significant difficulties in their 
attempts to address the recognition of initially-expected losses, and their failure to agree on this issue contributed importantly to their failure to achieve convergence on accounting for credit losses. After the standard setters eliminated from consideration EL methods that would spread the recognition of initially-expected losses over time such that they were recognised alongside credit-premium-inclusive interest revenue without day-1 losses, they were left with EL methods requiring the recognition of expected losses at each reporting date including day 1. The recognition of day-1 losses, which is easily justified for the purpose of determining banks' capital requirements, is not easily justified for the purpose of measuring credit-loss expense and loss allowances in financial statements, as exemplified by an informed commentator body's observation that proposals might wreak havoc with the FASB's conceptual framework, an alternative view from an IASB member and a dissenting opinion from two FASB members. Furthermore, the issue of day-1 losses acted in combination with differing preferences with regard to conservatism on the part of the IASB and the FASB, with the latter's more conservative preference for day-1 recognition of full-contractual-life expected losses appearing to be motivated in part by existing practice that had been subject to prudential-regulatory-related influence, to contribute significantly to the failure of FASB/IASB convergence. With the benefit of hindsight, it appears to us possible that positive outcomes might have been achieved in a more straightforward and converged manner if, after the elimination from consideration of a spreading-based EL approach, the standard setters had explored broader-information-set-based and more-responsive IL-type approaches that could have approximated the outcomes of an EL spreading approach without leading to day-1 losses.

In conversations with some observers, we reflected on whether the EL methods that have now been developed would have been more effective than the IL method in mitigating the effects of the financial and banking crisis. From these conversations, it appears to be 
widely believed that, although a less restrictive method might have had some beneficial effect, it is unlikely that any ex-ante acceptable method of accounting for credit-loss impairment would have substantially mitigated the consequences of a shock of the magnitude that occurred in the crisis. This view was also reflected in some comment letters. ${ }^{69}$ We note that the financial and banking crisis of the late 2000s started in the U.S., where loss recognition tended to occur earlier than elsewhere, which suggests the limited impact that differences in methods of accounting for credit losses might have with regard to crisis prevention. $^{70}$

Issues relating to whether a less radical route might have been advisable are expressed well in a comment letter on FASB/IASB (2011a) submitted by Sandler O'Neill Partners, a U.S. investment-banking firm: ${ }^{71}$

The incurred-loss impairment models in use during the financial crisis were criticized for (i) not recognizing losses soon enough, (ii) not incorporating information forward-looking enough to encompass the lifetime of assets and complete economic cycles, and (iii) not providing a uniform approach to the impairment of similar assets.

The problems of the recent financial crisis did not result from an inability to reserve for probable credit losses proactively enough. Rather, [...] the fundamental failure was underwriting $[\ldots]$.

To be clear, any bank capable of apprehending the magnitude of expected losses for the worst-performing assets during the financial crisis simply would not have originated or acquired those assets. Thus, the crux of the problem was not an incurred- versus expected-loss approach to reserves but, rather, that the financial system was awash in too many assets for which no reserve methodology would have been adequate. For the best banks, incurred-loss reserving worked just fine, and for the worst banks no impairment methodology would have helped because the fundamental failure was one of underwriting, not reserving.

There is a legal maxim that "hard cases make bad law." It posits that difficult or unusual facts provide a poor basis for a law or rule of general application that must cover a wider range of less extreme circumstances $[\ldots]$.

Targeted improvements to existing impairment methodology are far preferable to its overreaching replacement $[\ldots]$. 
It may be worthwhile to consider whether the events considered in this paper are an example of accounting standard setters, faced with exceptional economic events that prompted important questions about accounting but were not to a significant degree caused by accounting or preventable by accounting, taking a radical route instead of another less radical route that might have achieved substantial benefit at substantially lower cost. 


\section{Notes}

${ }^{1}$ See the FASB/IASB press release dated 20 October 2008, available from: http://www.fasb.org/news/nr102008.shtml [Accessed 18 August 2017].

2 For example, Hashim et al. (2016) report that loans typically account for $60 \%$ to $70 \%$ of banks' total assets. Ryan (2017) observes that 'the allowance for loan losses (which reduces loans outstanding) and the provision for loan losses (which reduces net income) are by far the most important and judgmental accrual estimates for most banks'.

${ }^{3}$ Throughout this paper, references to a method being perceived as conceptually strong denote that the method is perceived as faithfully representing the economic substance of activities. This is consistent with the way in which the term 'conceptual' is used in many of the comment letters examined by O'Hanlon et al. (2018) in their study of responses to the various proposals on accounting for credit losses issued by the IASB and/or the FASB between 2009 and 2013.

${ }^{4}$ See transcripts of remarks made by the SEC's Chief Accountant, Michael Sutton, in November 1997 (available from: https://www.sec.gov/news/speech/speecharchive/1997/spch195.txt) and by the SEC's Chairman, Arthur Levitt, $\quad$ in $\quad$ September 1998 (available from: https://www.sec.gov/news/speech/speecharchive/1998/spch220.txt) [Both accessed 10 April 2018].

${ }^{5} \mathrm{SAB} 102$ is available from: https://www.sec.gov/interps/account/sab102.htm [Accessed 10 April 2018].

${ }^{6}$ In a discussion of Beck and Narayanmoorthy (2013), Ryan and Keeley (2013) argue that SAB 102 did not express any preference for historical loss information in making allowance estimates, but acknowledge that the $\mathrm{SAB}$ requirements for the application of consistency and discipline may have delayed banks' recognition of losses on heterogeneous loans.

${ }^{7}$ Available from: https://www.occ.treas.gov/news-issuances/speeches/2009/pub-speech-2009-16.pdf [Accessed 10 April 2018].

${ }^{8}$ Prior to and during the deliberations leading up to the 2003 revision of IAS 39, the treatment of expected losses under the internal-ratings-based (IRB) approach to be introduced in Basel 2 (BCBS 2004b) was being considered by BCBS (BCBS 2001a, b, BCBS 2003, BCBS 2004a).

${ }^{9}$ Comment letters on FASB (2012) are available from:

http://www.fasb.org/jsp/FASB/CommentLetter_C/CommentLetterPage\&cid=1218220137090\&project_id=2012 -260 [Accessed 18 August 2017].

${ }_{10}$ Available from: https://www.aba.com/Advocacy/Issues/Documents/CECL-backgrounder.pdf [Accessed 24 April 2018]. As noted in IAS 39 (IASB 2003, paragraph AG90), IBNR denotes loss events of which a lender is unaware as at a reporting date but that can be assumed to have occurred prior to that reporting date, but not loss events expected to occur after that reporting date.

${ }^{11}$ Hodder and Hopkins (2014) refer to the requirement that regulatory accounting principles must be consistent with or no less stringent than GAAP. IASB (2014a, paragraph BC5.116) notes that 'the interaction between the role of prudential regulation and loss allowances is historically stronger in the U.S.'. A speaker at a European Parliament hearing on IFRS 9 commented that '... the whole history of U.S. GAAP accounting for loan losses is steeped in what the prudential regulators in the U.S. have required [...]' (Mike Ashley, European Parliament, 1 December 2015).

${ }^{12}$ A document containing the contribution by this speaker is available from: http://www.europarl.europa.eu/cmsdata/93535/Statement\%20Ashley\%20EN.pdf [Accessed 18 August 2017].

${ }^{13} \mathrm{Ng}$ and Roychowdhury (2014) examine the association between loan-loss allowances included in Tier 2 capital and bank failure. Their examination suggests that this element of Tier 2 capital does not behave like an element of capital that acts as a buffer against failure risk.

${ }^{14}$ Some banks that used the IRB approach also used the standardised approach for some business units, and their Tier 2 regulatory capital therefore continued to include some general loan-loss allowances.

${ }^{15}$ Practice in the U.S. is to treat the whole loss allowance as a general allowance for the purpose of calculating Tier 2 capital under the Basel standardised approach. For reference to this, see OCC (1998, p.4).

${ }^{16}$ U.S. IRB banks are required to satisfy the capital requirements of both the IRB approach and the standardised approach. (For a reference to this, see the Federal Register, Friday October 11, 2013, p. 62,021. This is available from: https://www.gpo.gov/fdsys/pkg/FR-2013-10-11/pdf/FR-2013-10-11.pdf [Accessed 20 April 2018].)

${ }^{17}$ Issues related to the trade-off between restricting earnings management and permitting discretion are sometimes considered in relation to a trade-off between 'relevance' and 'reliability'. In light of the fact that 'reliability' has now been removed as a qualitative characteristic from the IASB and FASB conceptual frameworks, we do not structure our review around this trade-off. 'Relevance' and 'reliability' were included as qualitative characteristics in the pre-2010 conceptual frameworks of the IASB and the FASB (FASB 1980, IASB 2001). The FASB and IASB 2010 conceptual frameworks removed the term 'reliability' from their qualitative characteristics on the ground that the term was ambiguous in the context of conceptual frameworks 
(FASB 2010b paragraphs BC3.20-BC3.24, IASB 2010 paragraphs BC3.20-BC3.24). This ambiguity had been noted by Ball (2006, p. 9). It is also noted in the IASB's 2018 Conceptual Framework (IASB 2018, paragraph BC2.29).

${ }^{18}$ The directional effects of loan-loss expense on earnings and regulatory capital are not necessarily the same. Loan-loss expense that decreases net-of-tax earnings and decreases shareholders' equity can increase regulatory capital if gross-of-tax loss allowances are included in regulatory capital.

${ }^{19}$ Prior to implementation in the U.S. in 1989 of the Basel 1 accord, loss allowances were included in primary capital. Subsequent to the implementation of Basel 1, which saw the introduction of a split of capital into Tier 1 and Tier 2, general loss allowances up to $1.25 \%$ of risk-weighted assets could be included in Tier 2 capital. The Basel 1 accord, issued in 1988, was implemented by the U.S. bank regulatory and supervisory agencies in 1989. (For a reference to this, see the Federal Register, Friday December 7, 2007, p. 69,289, footnote 3 . This is available from: https://www.gpo.gov/fdsys/pkg/FR-2007-12-07/pdf/FR-2007-12-07.pdf [Accessed 12 April 2018].)

${ }^{20} \mathrm{O}$ 'Hanlon (2013) finds no evidence that accounting for credit losses by U.K. banks became less timely after the move from the evidence requirements of pre-existing U.K. GAAP to those of IAS 39. However, it should be noted that accounting for credit losses under U.K. GAAP was already in accordance with incurred-loss and that the effect of the adoption of IAS 39 on accounting for credit losses in the U.K. was therefore likely to be less pronounced than in some other countries.

${ }^{21}$ The concept of 'prudence' featured in the pre-2010 conceptual frameworks of the FASB and the IASB, with the term 'conservatism' being used interchangeably with 'prudence' in the FASB framework. In both cases, it was emphasised that 'prudence' denoted the exercise of caution under conditions of uncertainty and should not lead to the systematic understatement of net asset values. The 2010 FASB and IASB conceptual frameworks, the term 'prudence' was removed because of the possibility that it might be incorrectly interpreted as encouraging downward bias in net asset values, which would be inconsistent with neutrality (FASB 2010b paragraphs BC3.27-BC3.28, IASB 2010 paragraphs BC3.27-BC3.28). In 2018, the IASB issued a revised conceptual framework. This reinstated the concept of 'prudence', again stating that the term is intended to denote the exercise of caution under conditions of uncertainty and not the systematic understatement of net asset values (IASB 2018, paragraph 2.16).

${ }^{22}$ For fuller discussion of conditional and unconditional conservatism in the general financial-reporting literature, see Watts (2003a), Watts (2003b), Beaver and Ryan (2005) and Ryan (2006).

${ }^{23}$ Evidence in Lee and Rose (2010) for U.S. bank holding companies for 2000-2009, from which Ryan (2017) quotes some figures, indicates that the average ratios of loan-loss allowance to equity, equity to total assets and loan-loss allowance to total assets are in the region of $10 \%, 10 \%$ and $1 \%$, respectively. These magnitudes are similar to those reported by Hashim et al. (2016, pp. 255-256) for 2007-2014 for U.S. banks and for banks in developed markets outside the U.S.

${ }^{24}$ The early stages of this activity took place against the background of proposals under which most financial instruments would be measured at fair value (IASB 2008, FASB 2010a). However, there was strong opposition to the proposed significant increase in the use of fair value, particularly for loans. Subsequent stages of development of new impairment methods took place in the expectation that a large proportion of financial assets, including loans, would continue to be measured at amortised cost.

${ }^{25}$ The European Parliament paper by O'Hanlon et al. (2015) was written before the FASB standard (FASB 2016) was finalised.

${ }^{26}$ See, for example, the letter from the Cigna Corporation in respect of IASB (2009): 'This proposed model that reports level investment returns implies consistent, level investment risk, which does not reflect actual performance or events. Credit risk changes over time for individual instruments and financial statement reporting should not inadvertently mask such changes.' Comment letters on IASB (2009) are available from: http://archive.ifrs.org/Current-Projects/IASB-Projects/Financial-Instruments-A-Replacement-of-IAS-39Financial-Instruments-Recognitio/Impairment/ED/Comment-Letters/Pages/Comment-letters.aspx [Accessed 24 April 2018].

${ }^{27}$ Some found it surprising that the FASB (2010a) proposals on credit-loss impairment differed so much from the IASB (2009) proposals, particularly in light of the aim at the time that the FASB and the IASB should work together on accounting for financial instruments. See the comment letter from the American Insurance Association (page 1). Comment letters on FASB (2010a) are available from: http://www.fasb.org/jsp/FASB/CommentLetter_C/CommentLetterPage\&cid=1218220137090\&project_id=18 $\underline{10-100}$ [Accessed 18 August 2017]. In relation to this point, IASB (2009) had noted that 'It is not uncommon for the boards to deliberate separately on joint projects and then subsequently to reconcile any differences in their technical decisions' (IASB 2009, paragraph IN13).

${ }^{28}$ The TPA allowance would be equal to all credit losses expected for the remaining portfolio life multiplied by the portfolio's age as a proportion of its expected life. 
${ }^{29}$ IASB (2013a) noted that the TPA spreading method differs from the IASB (2009) spreading method in that it spreads across time both the recognition of initially-expected losses and the recognition of subsequent changes in expectations about losses: 'The SD (supplementary document) attempted to reflect the relationship between expected credit losses and interest revenue using the TPA. The TPA reflects this relationship through the allocation of expected credit losses over time, 'adjusting' the contractual interest. However, it does this through a short-cut, and therefore the result does not represent the economics as faithfully as the 2009 ED (exposure draft) did. Because the TPA allocates over time both the initial expected credit losses and the subsequent changes in lifetime expected credit losses, the measurement results in an understatement of changes in expected credit losses until the entity recognises lifetime expected credit losses.' (IASB 2013a, paragraph BC35).

${ }^{30}$ O'Hanlon et al. (2018) categorised a total of 183 respondents to FASB/IASB (2011a) as being either non-U.S. respondents that could be assumed to be IASB constituents or potential constituents $(111(61 \%)$ ) or U.S. respondents that could be assumed to be FASB constituents (72 (39\%)). Some respondents (international accounting firms, international associations, international bank-regulatory organisations and other international regulatory organisations) were included in neither of these categories for the purpose of the statistics reported here.

${ }^{31}$ See the comment by the Chair of the IASB at a meeting of December 2012, which we quote in our subsection 3.4 .

${ }^{32}$ After August 2012, the IASB and the FASB continued to work towards convergence in some areas. For example, they issued a joint proposal on Leasing in 2013 (FASB 2013, IASB 2013c), although the FASB and the IASB eventually produced different standards in this area, and they issued a converged standard on Revenue Recognition in 2014 (FASB 2014, IASB 2014c). It therefore appears likely that, although the FASB's disengagement from the three-bucket deliberations may have been related to a broader move away from convergence in general, this in itself would not have stopped the attempts to achieve a converged common solution on credit-loss impairment. It appears likely that the dominant factor was the boards' inability to agree on the substance of the proposals.

${ }^{33}$ Recording available from: http://media.ifrs.org/2011/IASB/July/Impairment_session2.mp3 [Accessed 18 August 2017].

${ }^{34}$ Recording available from: http://media.ifrs.org/AP4Impairment18102012.mp3 [Accessed 18 August 2017].

${ }^{35}$ See paragraph 32 in agenda paper $5 \mathrm{~A}$, available from: http://archive.ifrs.org/Meetings/MeetingDocs/IASB/2012/October/Impairment-1012-05A.pdf [Accessed 18 August 2017].

${ }^{36}$ Recording available from: http://media.ifrs.org/2013/IASB/July/Impairment_AR5_PM.mp3 [Accessed 18 August 2017].

${ }^{37}$ Because the magnitude of loss allowances is affected by practice with regard to charge-offs as well as by the timeliness with which credit-loss expense is recognised, more timely recognition of credit losses does not necessarily lead to higher loss allowances. See Liu and Ryan (2006) for evidence that charge-offs may be used to obscure the effect on loss allowances of the management of credit-loss expense. For a given chargeoff practice and other things equal, more timely recognition of credit losses would give rise to larger allowances.

${ }^{38}$ Recording available from: http://media.ifrs.org/2012/IASBMeetings/December/ImpairmentAR5141212.mp3 [Accessed 18 August 2017].

${ }^{39}$ Recording available from: http://media.ifrs.org/2012/IASBMeetings/December/ImpairmentAR5141212.mp3 [Accessed 18 August 2017].

40 IASB (2013a) defined 12-month expected credit losses for a loan for which credit risk has not increased significantly since initial recognition to be the product of (i) the gross carrying amount of the loan, (ii) the proportion of the gross carrying amount of the loan expected to be lost if the loan defaults (loss given default) and (iii) the probability of default over the next 12 months (IASB 2013a, paragraphs IE2-IE3).

${ }^{41}$ Recording available from: http://media.ifrs.org/2013/IASB/September/Impairment_AR5_Session1.mp3 [Accessed 18 August 2017].

42 The three-stage terminology from IASB (2013a) is not used in the standard itself, but is used in an IASB summary document (IASB 2014b, p. 18).

${ }^{43}$ See, for example, paragraph 6 in the document available from: http://archive.ifrs.org/Meetings/MeetingDocs/IASB/2013/July/5D-Impairment.pdf [Accessed 18 August 2017].

${ }^{44}$ This point was stressed in communications with stakeholders, including at the FASB roundtable meeting of 4 February 2016 attended by representatives of Community Banks at which the representatives expressed serious concern about the forecasting requirements of CECL.

${ }^{45}$ For references to such activities, see: 
- IASB March 2010 - available from: http://archive.ifrs.org/Current-Projects/IASB-Projects/FinancialInstruments-A-Replacement-of-IAS-39-Financial-Instruments-Recognitio/Impairment/MeetingSummaries/Documents/FI 0310b13Aobs.pdf (paragraphs 9 and 10) [Accessed 1December 2017];

- FASB/IASB April 2011 - available from: http://archive.ifrs.org/Current-Projects/IASBProjects/Financial-Instruments-A-Replacement-of-IAS-39-Financial-Instruments-

Recognitio/Impairment/Meeting-Summaries/Documents/FI0411b04Eobs.pdf (paragraphs 2 and 52-54) [Accessed 1December 2017];

- IASB October 2012 - available from: http://archive.ifrs.org/Meetings/MeetingDocs/IASB/2012/October/Impairment-1012-05A.pdf (paragraph 32) ) [Accessed 1December 2017];

- IASB July 2013 - available from: http://archive.ifrs.org/Meetings/MeetingDocs/IASB/2013/July/05AImpairment.pdf (paragraphs 33-37), [Accessed 1December 2017].

46 Available from: http://archive.ifrs.org/Meetings/MeetingDocs/IASB/2013/July/05A-Impairment.pdf (paragraph 35) [Accessed 1 December 2017].

${ }^{47}$ Of the 1,588 comment letters examined by O'Hanlon et al. (2018), 47 (3\%) were from financial and banking regulators.

${ }^{48}$ Of the total of 510 letters in response to FASB (2012) and IASB (2013a) examined by O'Hanlon et al. (2018), $14(3 \%)$ were from financial and/or banking regulatory bodies.

${ }^{49}$ See question 23 in a document published by the American Bankers' Association, available from: https://www.aba.com/Advocacy/Issues/Documents/CECL-backgrounder.pdf [Accessed 26 April 2018].

${ }^{50}$ It should be noted that the situation described here differs from one in which a loan might be made on terms favourable to the borrower such that the fair value of the expected recoverable amount is less than the amount lent. In such a situation, it would be uncontroversial that the loan should be written down to fair value at day 1 .

${ }^{51}$ For conceptual framework documents, see FASB (2010b) and IASB (2010).

${ }^{52}$ See, for example, the letter from the Illinois CPA Society commenting on FASB (2012): 'We believe the fundamental premise on which the Proposed ASU rests is at odds with the Conceptual Framework. [...] By requiring banks to recognize a provision for current expected credit losses for at-market loans at inception the Proposed ASU would require banks to recognize expected credit losses twice - once through the initial pricing of the loan and again through the separate day one loss allowance. This results in financial statements that do not faithfully represent the economic phenomenon of the issuance of an at-market loan, whereby neither party has realized an economic gain or loss.' Comment letters on FASB (2012) are available from: http://www.fasb.org/jsp/FASB/CommentLetter_C/CommentLetterPage\&cid=1218220137090\&project_id=2012 $\frac{-260}{53}$ [Accessed 18 August 2017].

${ }^{53}$ A discounted-cash-flow (DCF) approach is only one of various methods by which loss allowances may be determined under the FASB's CECL method.

${ }^{54}$ See, for example, the letter from Duff and Phelps LLC commenting on FASB (2012): 'One theoretical flaw in the model is that the discount rate applied to the expected credit losses (effective interest rate) already takes into account the credit risk priced in by the lender at origination and would have the effect of double-counting the initial estimate of credit losses.' Comment letters on FASB (2012) are available from:

http://www.fasb.org/jsp/FASB/CommentLetter_C/CommentLetterPage\&cid=1218220137090\&project_id=2012 $-\frac{-260}{55}$ [Accessed 18 August 2017].

${ }^{55}$ See, for example, the letter from UDVA commenting on FASB/IASB (2011a). With respect to the proposal for day-1 recognition of foreseeable-future-period (FFP) losses, this respondent says that this treatment is '[...] inconsistent with initial recognition of financial instruments at fair value as the transaction price (fair value in an arm's length transaction) already reflects the expected losses.' Comment letters on FASB/IASB (2011a) are available from:

http://www.fasb.org/jsp/FASB/CommentLetter_C/CommentLetterPage\&cid=1218220137090\&project_id=20 11-150 [Accessed 18 August 2017].

${ }^{56}$ See, for example, the letter from the Canadian Bankers Association commenting on FASB (2012): ' We do not believe that recognizing all interest earned over the life of the loan and total lifetime expected credit losses at inception is an appropriate reflection of the economics of the loan transaction.' Comment letters on FASB (2012) are available from:

http://www.fasb.org/jsp/FASB/CommentLetter_C/CommentLetterPage\&cid=1218220137090\&project_id=2012 $\underline{-260}$ [Accessed 18 August 2017].

${ }^{57}$ See, for example, the letter from Cisco Systems, Inc. commenting on FASB (2012): 'Recognition of ECL (expected credit losses) at inception would contribute to significant income statement volatility and provides an avenue for potential earnings management. For example, under the Proposal, we would record a credit loss at the time of purchase of a financial instrument that is not driven by an economic event. Subsequently, if we 
sold the same financial instrument in a different reporting period, we may record a gain even though there is not a change in credit risk.' Comment letters on FASB (2012) are available from:

http://www.fasb.org/jsp/FASB/CommentLetter_C/CommentLetterPage\&cid=1218220137090\&project_id=2012 -260 [Accessed 18 August 2017].

${ }^{58}$ See paragraph B21 in the document available from: http://archive.ifrs.org/Meetings/MeetingDocs/IASB/2013/July/5D-Impairment.pdf [Accessed 18 August 2017].

${ }^{59}$ See, for example, the letter from the Federal Financial Institution Regulatory Agencies in respect of FASB (2012): 'We have observed that credit losses typically emerge relatively early in the life of loans and do not occur ratably over a financial instrument's life.' Comment letters on FASB (2012) are available from:

http://www.fasb.org/jsp/FASB/CommentLetter_C/CommentLetterPage\&cid=1218220137090\&project id=2012 -260 [Accessed 18 August 2017].

${ }^{60}$ See, for example, the letter from Carlson Capital LP in respect of FASB (2010a): 'Our long-held view is that there is an inherent risk of loss from the moment every dollar is lent.' Comment letters on FASB (2010a) are available from:

http://www.fasb.org/jsp/FASB/CommentLetter_C/CommentLetterPage\&cid=1218220137090\&project_id=18 10-100 [Accessed 18 August 2017].

${ }_{61}$ This passage is from the response to question 3 in a FASB 'Frequently Asked Questions' document available from:

http://www.fasb.org/cs/BlobServer?blobkey=id\&blobwhere=1175826417092\&blobheader=application/pdf\&b lobcol=urldata\&blobtable=MungoBlobs [Accessed 18 August 2017].

62 Available from: https://www.aba.com/Advocacy/LetterstoCongress/Documents/RussellGolden-FASB011316.pdf [Accessed 26 April 2018].

${ }^{63}$ IASB (2014a, paragraph BCE.93 (d)) notes the benefit of the broadened information set in making credit-loss impairment more forward-looking.

${ }^{64}$ See paragraph A6 in the document available from: http://archive.ifrs.org/Meetings/MeetingDocs/IASB/2013/July/5D-Impairment.pdf [Accessed 18 August 2017].

${ }^{65}$ Comment letters on IASB (2013a) are available from: http://archive.ifrs.org/Current-Projects/IASBProjects/Financial-Instruments-A-Replacement-of-IAS-39-Financial-InstrumentsRecognitio/Impairment/Exposure-Draft-March-2013/Comment-letters/Pages/Comment-letters.aspx [Accessed 18 August 2017].

${ }^{66}$ Comment letters on FASB (2012) are available from:

http://www.fasb.org/jsp/FASB/CommentLetter_C/CommentLetterPage\&cid=1218220137090\&project id=2012 $\underline{-260}$ [Accessed 18 August 2017].

${ }^{67}$ Comment letters on FASB/IASB (2011a) are available from: http://www.fasb.org/jsp/FASB/CommentLetter_C/CommentLetterPage\&cid=1218220137090\&project id=20 11-150 [Accessed 18 August 2017].

${ }_{68}$ O'Hanlon et al. (2018, p. 23) report that a substantial number of US respondents to the 2012 FASB exposure draft and some non-U.S. respondents to the 2013 IASB exposure draft expressed preference for a modified and less restrictive IL-based approach over an EL-based approach.

${ }^{69} \mathrm{See}$, for example, the letter from BDO in respect of IASB (2009): 'We are not convinced that an expected loss model would have done anything to identify the onset of the global financial crisis at an earlier stage, or reduce the extent of the impairment losses that were reported after the onset of the global financial crisis.' Comment letters on IASB (2009) are available from: http://archive.ifrs.org/Current-Projects/IASBProjects/Financial-Instruments-A-Replacement-of-IAS-39-Financial-InstrumentsRecognitio/Impairment/ED/Comment-Letters/Pages/Comment-letters.aspx [Accessed 24 April 2018].

${ }^{70} \mathrm{We}$ did not see any evidence that the standard setters themselves saw any contradiction in the fact that the crisis had started in the U.S., where loss recognition tended to occur earlier than elsewhere.

${ }^{71}$ Comment letters on FASB/IASB (2011a) are available from: http://www.fasb.org/jsp/FASB/CommentLetter_C/CommentLetterPage\&cid=1218220137090\&project id=20 11-150 [Accessed 18 August 2017]. 


\section{References}

Acharya, V. and Ryan, S., 2016. Banks' financial reporting and financial system stability. Journal of Accounting Research, 54 (2), 277-340.

Ahmed, A., Takeda, C. and Thomas, S., 1999. Bank loan loss provisions: a re-examination of capital management, earnings management and signaling effects. Journal of Accounting and Economics, 28 (1), 1-25.

Aier, J., Chen, L. and Pevzner, M., 2014. Debtholders' demand for conservatism: evidence from changes in directors' fiduciary duties. Journal of Accounting Research, 52 (5), 9931027.

Akins, B., Dou, Y. and Ng, J., 2017. Corruption in bank lending: The role of timely loan loss recognition. Journal of Accounting and Economics, 63 (2-3), 454-478.

Anandarajan, A., Hasan, I. and McCarthy, C., 2007. Use of loan loss provisions for capital, earnings management and signalling by Australian banks. Accounting and Finance, 47 (3), 357-379.

BCBS, 1988. International Convergence of Capital Measurement and Capital Standards. July 1988. Bank for International Settlements.

BCBS, 2001a. Consultative Document: The New Basel Capital Accord. January 2001. Bank for International Settlements.

BCBS, 2001b. Working Paper on the IRB Treatment of Expected Losses and Future Margin Income. July 2001. Bank for International Settlements.

BCBS, 2003. Consultative Document: The New Basel Capital Accord. April 2003. Bank for International Settlements.

BCBS, 2004a. Modifications to the Capital Treatment for Expected and Unexpected Credit losses in the New Basel Accord. January 2004. Bank for International Settlements. 
BCBS, 2004b. International Convergence of Capital Measurement and Capital Standards: A Revised Framework. June 2004. Bank for International Settlements.

BCBS, 2006. International Convergence of Capital Measurement and Capital Standards: A Revised Framework - Comprehensive Version. June 2006. Bank for International Settlements.

BCBS, 2009. Guiding Principles for the Replacement of IAS 39. August 2009. Bank for International Settlements.

BCBS, 2011. Basel III: A Global Regulatory Framework for More Resilient Banks and Banking Systems. June 2011. Bank for International Settlements.

Ball, R., 2006. International Financial Reporting Standards (IFRS): pros and cons for investors. Accounting and Business Research, 36 (Sup 1), 5-27.

Ball, R. and Shivakumar, L., 2005. Earnings quality in UK private firms: comparative loss recognition timeliness. Journal of Accounting and Economics, 39 (1), 83-128.

Balla, E. and Rose, M., 2015. Loan loss provisions, accounting constraints, and bank ownership structure. Journal of Economics and Business, 78 (March-April), 92-117.

Basu, S., 1997. The conservatism principle and the asymmetric timeliness of earnings. Journal of Accounting and Economics, 24 (1), 3-37.

Beatty, A., Chamberlain, S. and Magliolo, J., 1995. Managing financial reports of commercial banks: the influence of taxes, regulatory capital, and earnings. Journal of Accounting Research, 33 (2), 231-261.

Beatty, A. and Liao, S., 2011. Do delays in expected loss recognition affect banks' willingness to lend? Journal of Accounting and Economics, 52 (1), 1-20.

Beaver, W. and Ryan, S., 2005. Conditional and unconditional conservatism: concepts and modelling. Review of Accounting Studies, 10 (2-3), 269-309. 
Beck, P. and Narayanamoorthy, G., 2013. Did the SEC impact banks' loan loss reserve policies and their informativeness? Journal of Accounting and Economics, 56 (2-3), 4265.

Benston, G. and Wall, L., 2005. How should banks account for loan losses? Journal of Accounting Public Policy, 24 (2), 81-100.

Bikker, J. and Metzemakers, P., 2005. Bank provisioning behaviour and procyclicality. Journal of International Financial Markets, Institutions and Money, 15 (2), 141-157.

Bouvatier, V. and Lepetit, L., 2008. Banks' procyclical behavior: Does provisioning matter? Journal of International Financial Markets, Institutions and Money, 18 (5), 513-526.

Bouvatier, V. Lepetit, L. and Strobel, F., 2014. Bank income smoothing, ownership concentration and the regulatory environment. Journal of Banking and Finance, 41 (April), 253-270.

Bushman, R. and Williams, C., 2012. Accounting discretion, loan loss provisioning, and discipline of Banks' risk-taking. Journal of Accounting and Economics, 54 (1), 1-18.

Bushman, R. and Williams, C., 2015. Delayed expected loss recognition and the risk profile of banks. Journal of Accounting Research, 53 (3), 511-553.

Camfferman, K., 2015. The emergence of the 'incurred-loss' model for credit losses in IAS 39. Accounting in Europe, 12 (1), 1-35.

Collins, J., Shackelford, D. and Wahlen, J., 1995. Bank differences in the coordination of regulatory capital, earnings, and taxes. Journal of Accounting Research, 33 (2), 263-291.

FASB, 1975. Statement of Financial Accounting Standards No. 5: Accounting for Contingencies (SFAS 5). March 1975. Financial Accounting Standards Board.

FASB, 1980. Statement of Financial Accounting Concepts No.2 Qualitative Characteristics of Accounting Information. May 1980. Financial Accounting Standards Board. 
FASB, 1993a. Statement of Financial Accounting Standards No. 114: Accounting by Creditors for Impairment of a Loan (SFAS 114). May 1993. Financial Accounting Standards Board.

FASB, 1993b. Statement of Financial Accounting Standards No. 115: Accounting for Certain Investments in Debt and Equity Securities (SFAS 115). May 1993. Financial Accounting Standards Board.

FASB, 2010a. Exposure Draft: Proposed Accounting Standards Update. Accounting for Financial Instruments and Revisions to the Accounting for Derivative Instruments and Hedging Activities. 26 May 2010. Financial Accounting Standards Board.

FASB, 2010b. Statement of Financial Accounting Concepts No. 8. Conceptual Framework for Financial Reporting. September 2010. Financial Accounting Standards Board.

FASB, 2012. Exposure Draft: Proposed Accounting Standards Update. Financial Instruments: Credit Losses. 20 December 2012. Financial Accounting Standards Board.

FASB, 2013. Exposure Draft: Proposed Accounting Standards Update (Revised). Leases. 16 May 2013. Financial Accounting Standards Board.

FASB, 2014. Accounting Standards Update No. 2014-09. Revenue from Contracts with Customers (Topic 606). May 2014. Financial Accounting Standards Board.

FASB, 2016. Accounting Standards Update No. 2016-13. Financial Instruments - Credit Losses (Topic 326): Measurement of Credit Losses on Financial Instruments. June 2016. Financial Accounting Standards Board.

FASB/IASB, 2011a. Supplementary Document. Accounting for Financial Instruments and Revisions to the Accounting for Derivative Instruments and Hedging Activities: Impairment. 31 January 2011. Financial Accounting Standards Board; AND Supplement to ED/2009/12. Financial Instruments: Amortised Cost and Impairment (Financial Instruments: Impairment). January 2011. International Accounting Standards Board. 
FASB/IASB, 2011b. Staff Paper. Impairment: Three-Bucket Approach - IASB/FASB Meeting in week commencing 13 June 2011, Agenda Reference 8. Available from: http://archive.ifrs.org/Current-Projects/IASB-Projects/Financial-Instruments-AReplacement-of-IAS-39-Financial-Instruments-Recognitio/Impairment/MeetingSummaries/Documents/FI0611b08obs.pdf [Accessed 18 August 2017].

FFIEC, 2001. Policy Statement on Allowance for Loan and Lease Losses Methodologies and Documentation for Banks and Savings Institutions. July 2001. Federal Financial Institutions Examination Council.

Financial Crisis Advisory Group, 2009. Report of the Financial Crisis Advisory Group. 28 July 2009. Financial Crisis Advisory Group.

Financial Stability Board, 2009. Improving Financial Regulation: Report of the Financial Stability Board to G20 Leaders. 25 September 2009. Financial Stability Board.

Fonseca, A. and Gonzalez, F., 2008. Cross-country determinants of bank income smoothing by managing loan-loss provisions, Journal of Banking and Finance, 32 (February), 217228.

GAO, 1991. Failed Banks: Accounting and Auditing Reforms Urgently Needed. April 1991. United States General Accounting Office

GAO, 1992. Flexible Accounting Rules Lead to Inflated Financial Reports. June 1992. United States General Accounting Office

Garcia Lara, J., Garcia Osma, B. and Penalva, F., 2016. Accounting conservatism and firm investment efficiency. Journal of Accounting and Economics, 61 (1), 221-238.

Gebhardt, G. and Novotny-Farkas, Z., 2011. Mandatory IFRS adoption and accounting quality of European banks. Journal of Business Finance and Accounting, 38 (3-4), 289333. 
Giner, B. and Mora, A., 2018. Bank loan loss accounting and its contracting effects: the new expected loss models. Working Paper, University of Valencia.

Hasan, I. and Wall, L., 2004. Determinants of the loan loss allowance: some cross- country comparisons. Financial Review, 39 (1), 129-152.

Hashim, N., Li, W. and O'Hanlon, J., 2016. Expected-loss-based accounting for impairment of financial instruments: The FASB and IASB proposals 2009-2016. Accounting in Europe, 13 (2), 229-267.

Hodder, L. and Hopkins, P., 2014. Agency problems, accounting slack, and banks' response to proposed reporting of loan fair values. Accounting, Organizations and Society 39 (2), 117-133.

Huizinga, H. and Laeven, L., 2012. Bank valuation and accounting discretion during a financial crisis. Journal of Financial Economics, 106 (3), 614-634.

IASB, 2000. International Accounting Standard 39 - Financial Instruments: Recognition and Measurement. October 2000. International Accounting Standards Board.

IASB, 2001. Framework for the Preparation and Presentation of Financial Statements. April 2001. International Accounting Standards Board.

IASB, 2003. International Accounting Standard 39 - Financial Instruments: Recognition and Measurement. December 2003. International Accounting Standards Board.

IASB, 2008. Reducing Complexity in Reporting Financial Instruments. March 2008. International Accounting Standards Board.

IASB, 2009. Exposure Draft ED/2009/12. Financial Instruments: Amortised Cost and Impairment. November 2009. International Accounting Standards Board.

IASB, 2010. The Conceptual Framework for Financial Reporting. September 2010. International Accounting Standards Board. 
IASB, 2013a. Exposure Draft ED/2013/3 Financial Instruments: Expected Credit Losses. March 2013. International Accounting Standards Board.

IASB, 2013b. Snapshot: Financial Instruments - Expected Credit Losses. March 2013. International Accounting Standards Board.

IASB, 2013c. Exposure Draft ED/2013/6 Leases. May 2013. International Accounting Standards Board.

IASB, 2014a. IFRS 9 Financial Instruments. July 2014. International Accounting Standards Board.

IASB, 2014b. Project Summary. IFRS 9 Financial Instruments. July 2014. Available from: http://archive.ifrs.org/Current-Projects/IASB-Projects/Financial-Instruments-A-

Replacement-of-IAS-39-Financial-Instruments-Recognitio/Documents/IFRS-9-ProjectSummary-July-2014.pdf [Accessed 18 August 2017].

IASB, 2014c. IFRS 15 Revenue from Contracts with Customers. May 2014. International Accounting Standards Board.

IASB, 2018. Conceptual Framework for Financial Reporting. March 2018. International Accounting Standards Board.

Jin, J., Kanagaretnam, K. and Lobo, G., 2016. Discretion in bank loan loss allowance, risk taking and earnings management. Accounting and Finance, 58 (1), 1-23.

Kanagaretnam, K., Lobo, G. and Mathieu, R., 2003. Managerial incentives for income smoothing through bank loan loss provisions. Review of Quantitative Finance and Accounting, 20 (1), 63-80.

Kanagaretnam, K., Lobo, G., and Yang, D., 2004. Joint tests of signaling and income smoothing through bank loan loss provisions. Contemporary Accounting Research, 21 (4), 843-884. 
Kane, E., 1997. Ethical foundations of financial regulation. Journal of Financial Services Research, 12 (1), 51-74.

Kim, M. and Kross, W., 1998. The impact of the 1989 change in bank capital standards on loan loss provisions and loan write-offs. Journal of Accounting and Economics, 25 (1), 69-99.

Kruger, S., Rosch, D. and Scheule, H., 2018. The impact of loan loss provisioning on bank capital requirements. Journal of Financial Stability, 36 (June), 114-129.

Laeven, L. and Majnoni, G., 2003. Loan loss provisioning and economic slowdowns: too much, too late? Journal of Financial Intermediation, 12 (2), 178-197.

LaFond, R. and Watts, R., 2008. The information role of conservatism. Accounting Review, $83(2), 447-478$.

Lee, S. and Rose J., 2010. Profits and balance sheet developments at U.S. commercial banks in 2009. Federal Reserve Bulletin 96.

Lim, C., Lee, E. and Walker, M., 2015. Bank accounting conservatism and bank loan pricing, Journal of Accounting and Public Policy, 33 (3), 260-278.

Liu, C. and Ryan, S., 2006. Income smoothing over the business cycle: changes in banks' coordinated management of provisions for loan losses and loan charge-offs from the pre1990 bust to the 1990s boom. Accounting Review, 81 (2), 421-441.

Lobo, G. and Yang, D., 2001. Bank managers' heterogeneous decisions on discretionary loan loss provisions. Review of Quantitative Finance and Accounting, 16 (3), 223-250.

Marton, J. and Runesson, E., 2017. The predictive ability of loan loss provisions in banks effects of accounting standards, enforcement and incentives. British Accounting Review, $49(2), 162-180$.

McEnroe, J. and Sullivan, M., 2014. Convergence movement - have there been benefits to the convergence process? CPA Journal, January, 15-19. 
Moyer, S., 1990. Capital adequacy ratio regulations and accounting choices in commercial banks. Journal of Accounting and Economics, 13 (2), 123-154.

Meyer, L., 1999. Testimony of Governor Laurence H. Meyer: Loan-loss Reserves Before the Subcommittee on Financial Institutions and Consumer Credit, Committee on Banking and Financial Services, U.S. House of Representatives. June 1999. Available from: https://www.federalreserve.gov/boarddocs/testimony/1999/19990616.htm [Accessed 24 April 2018].

Nichols, D., Wahlen, J. and Wieland, M., 2009. Publicly traded versus privately held: implications for conditional conservatism in bank accounting. Review of Accounting Studies, 14 (1), 88-122.

Ng, J. and Roychowdhury, S., 2014. Do loan loss reserves behave like capital? Evidence from recent bank failures, Review of Accounting Studies, 19 (3), 1234-1279.

Novotny-Farkas, Z., 2016. The interaction of the IFRS 9 expected loss approach with supervisory rules and implications for financial stability. Accounting in Europe, 13 (2), $197-227$.

OCC, 1998. Allowance for Loan and Lease Losses. May 1998. Office of the Comptroller of the Currency.

O'Hanlon, J., 2013. Did loan-loss provisioning by UK banks become less timely after implementation of IAS 39? Accounting and Business Research, 43 (3), 225-258.

O'Hanlon, J., Hashim N. and Li, W., 2015. Expected-Loss-Based Accounting for the Impairment of Financial Instruments: the FASB and IASB IFRS 9 Approaches. European Parliament, ref: IP/A/ECON/2015-14/PE 563.463. Available from: http://www.europarl.europa.eu/RegData/etudes/STUD/2015/563463/IPOL_STU(2015)5 63463_EN.pdf [Accessed 18 August 2017]. 
O'Hanlon, J., Hashim N. and Li, W., 2018. Research Briefing - Accounting for Credit Losses: The Development of IFRS 9 and CECL. Institute of Chartered Accountants Charitable Trusts.

Perez, D., Salas-Fumas, V. and Saurina, J., 2008. Earnings and capital management in alternative loan loss provision regulatory regimes. European Accounting Review, 17 (3), 423-445.

Roychowdhury, S. and Watts, R., 2007. Asymmetric timeliness of earnings, market-to-book and conservatism in financial reporting. Journal of Accounting and Economics, 44 (1-2), $2-31$.

Rushton, E., 1999. Opening Statement of Emory W. Rushton Concerning Loan Loss Reserves Before the Subcommittee on Financial Institutions. June, 1999, Committee on Banking and Financial Services.

Ryan, S., 2006. Identifying conditional conservatism. European Accounting Review, 15 (4), $511-525$

Ryan, S., 2017. Is banks' current regulatory capital adequacy the mechanism by which their accounting requirements affect financial stability? Working Paper, New York University.

Ryan, S. and Keeley, J., 2013. Discussion of "Did the SEC impact banks' loan loss reserve policies and their informativeness?". Journal of Accounting and Economics, 56 (2-3), $66-78$.

SEC, 2012. Work Plan for the Consideration of Incorporating International Financial Reporting Standards into the Financial Reporting System for U.S. Issuers Final Staff Report. 13 July 2012. Securities and Exchange Commission.

Shrieves, R. and Dahl, D., 2003. Discretionary accounting and the behavior of Japanese banks under financial duress. Journal of Banking \& Finance, 27 (3), 1219-1243. 
Vyas, D., 2011. The timeliness of accounting write-downs by U.S. financial institutions during the financial crisis of 2007-2008. Journal of Accounting Research, 49 (3), 823860.

Wall, L. and Koch, T., 2000. Bank loan-loss accounting: A review of theoretical and empirical evidence. Economic Review - Federal Reserve Bank of Atlanta, 85 (2), 1-19.

Watts, R., 2003a. Conservatism in accounting part I: explanations and implications. Accounting Horizons, 17 (3), 207-221.

Watts, R., 2003b. Conservatism in accounting part II: evidence and research opportunities. Accounting Horizons, 17 (4), 287-301.

Wu, D., 2016. Practical issues in the Current Expected Credit Loss (CECL) model: effective loan life and forward-looking information. Working Paper, Office of the Comptroller of the Currency.

Zhang, J., 2008. The contracting benefits of accounting conservatism to lenders and borrowers. Journal of Accounting and Economics, 45 (1), 27-54. 
Figure 1: Expected Loss Approaches to Credit-Loss Impairment: Documents Issued by FASB and/or IASB from 2009 to 2016

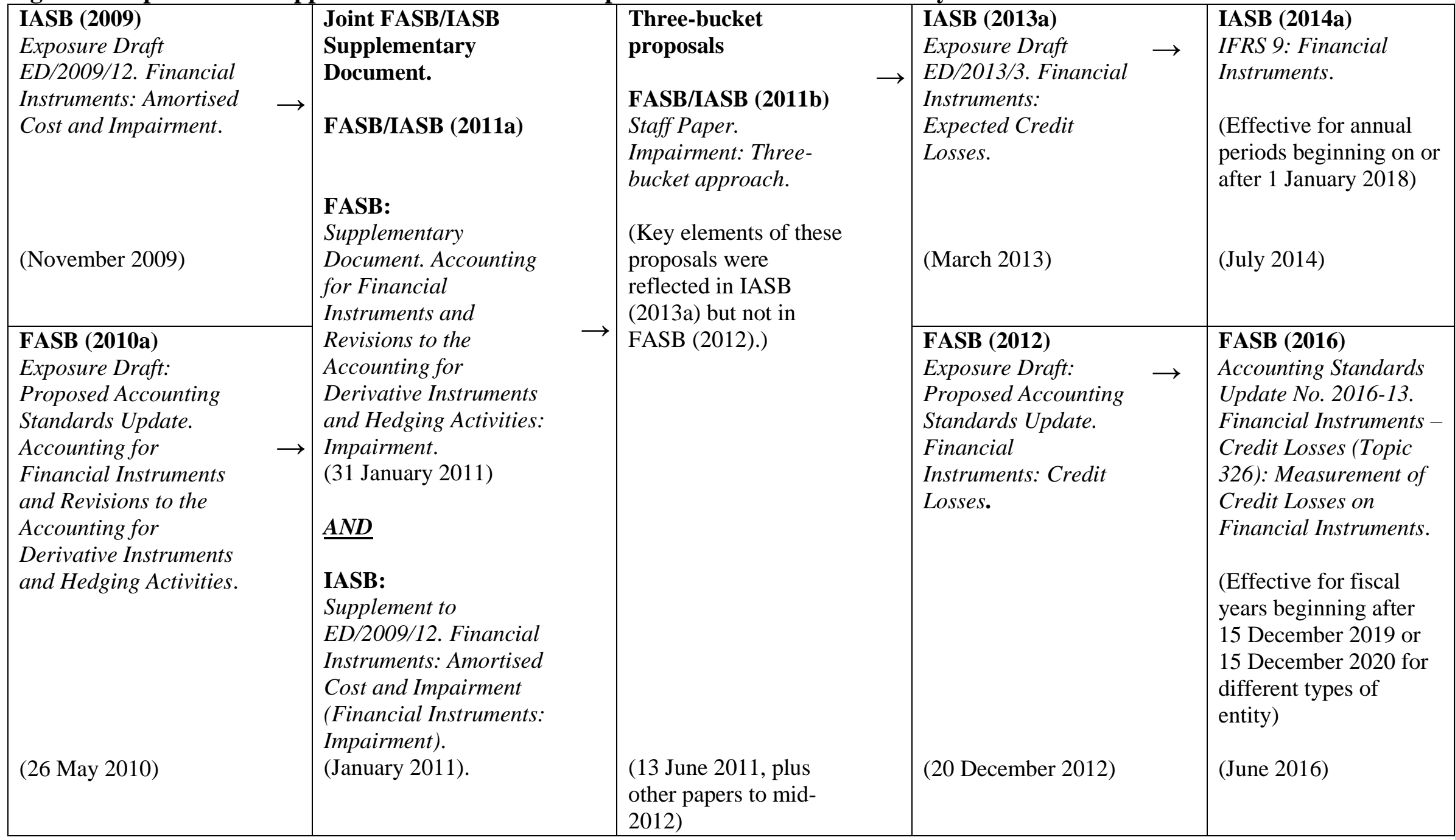


Figure 2: Recognition of initially-expected credit losses under IASB (2009)

\section{Panel A}

Recognition of credit losses if initial expectations are realised

Percentage of gross

carrying amount

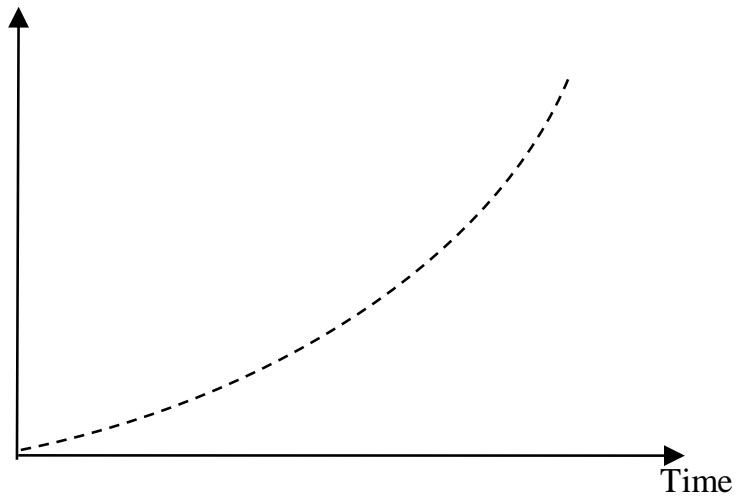

\section{Panel B}

Recognition of credit losses if initial expectations are subsequently revised upwards

Percentage of gross

carrying amount

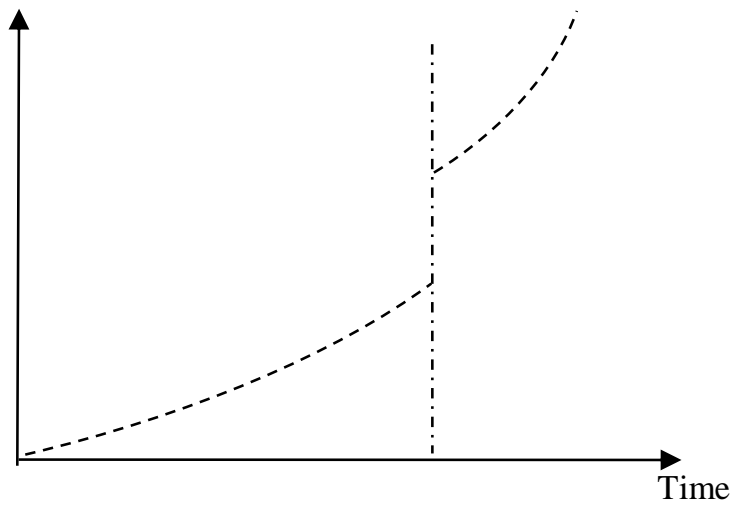

Panel A is based on a diagram from IASB (2013b). 
Figure 3: Numerical illustration of the IASB (2009) integrated-effective-interest-rate approach and of day-1 recognition of lifetimes expected losses

\section{The IASB (2009) integrated-effective-interest-rate approach}

A bank originates at the start of year 1 (designated here 'day 1') a portfolio of loans totalling Currency Units (CU) 1,000.00. It is believed that the fair value of the portfolio at origination is $\mathrm{CU} 1,000.00$.

Panel 1 of the table below gives the contractual cash flows due from the borrowers and the cash flows (net of expected credit losses) that, as at day 1, the bank expects to collect. Cash flows are expected to occur at yearly intervals, with 'Year 1' being one year after 'Day 1', etc. The effective interest rates based on contractual and expected cash flows are $10 \%$ and $8 \%$, respectively. Panel 2 of the table gives the movements on the loan account (net book value) as they would be if the cash flows expected as at day-1 were received and were accounted for under the integrated effective interest rate (IEIR) method proposed in IASB (2009).

\begin{tabular}{|c|c|c|c|c|c|c|c|}
\hline & \multicolumn{3}{|c|}{ Panel 1} & \multicolumn{4}{|c|}{ Panel 2} \\
\hline & \multicolumn{3}{|c|}{ Expectations as at day 1} & \multicolumn{4}{|c|}{$\begin{array}{l}\text { Based on cash flows expected as at day-1, under } \\
\text { the IASB (2009) IEIR method }\end{array}$} \\
\hline & $\begin{array}{r}\text { Contractual } \\
\text { cash flows }\end{array}$ & $\begin{array}{r}\text { Expected } \\
\text { credit } \\
\text { losses }\end{array}$ & $\begin{array}{r}\text { Expected } \\
\text { cash flows } \\
\text { net of credit } \\
\text { losses }\end{array}$ & $\begin{array}{l}\text { Brought } \\
\text { forward }\end{array}$ & $\begin{array}{l}\text { Interest } \\
\text { accrued } \\
(\text { at } 8 \%)\end{array}$ & Cash & $\begin{array}{r}\text { Carried } \\
\text { forward }\end{array}$ \\
\hline Day 1 & $-1,000.00$ & & $-1,000.00$ & & & $1,000.00$ & $1,000.00$ \\
\hline Year 1 & 350.00 & -5.00 & 345.00 & $1,000.00$ & 80.00 & -345.00 & 735.00 \\
\hline Year 2 & 325.00 & -10.00 & 315.00 & 735.00 & 58.80 & -315.00 & 478.80 \\
\hline Year 3 & 300.00 & -16.00 & 284.00 & 478.80 & 38.30 & -284.00 & 233.10 \\
\hline Year 4 & 275.00 & -23.25 & 251.75 & 233.10 & 18.65 & -251.75 & 000.00 \\
\hline $\begin{array}{l}\text { Effective interest } \\
\text { rate (EIR) }\end{array}$ & $10 \%$ & & $8 \%$ & & & & \\
\hline
\end{tabular}

\section{Day-1 recognition of lifetimes expected losses}

This illustration uses the numbers given in the table above.

The fair value of the CU 1,000.00 of the portfolio of loans can be written as the present value of the contractual cash flows discounted at the EIR based on contractual cash flows (10\%):

$$
350.00 / 1.10+325.00 / 1.10^{2}+300.00 / 1 \cdot 10^{3}+275.00 / 1.10^{4}=C U 1,000.00 .
$$

It can also be written as follows as the expected cash flows discounted at the IEIR based on expected cash flows $(8 \%)$ :

$$
345.00 / 1.08+315.00 / 1.08^{2}+284.00 / 1.08^{3}+251.75 / 1.08^{4}=C U 1,000.00
$$

In illustrating the recognition of lifetime expected losses at day 1, 'loss' is estimated using discounted-cash-flow (DCF). In measuring impairment of financial assets, DCF is required under IASB (2014a) and is permitted, but not required, under FASB (2016). The net book value of the portfolio after subtracting the day-1 loss would be measured as follows by discounting the expected cash flows, net of expected credit losses, at the contractual EIR of $10 \%$ :

$345.00 / 1.10+315.00 / 1.10^{2}+284.00 / 1.10^{3}+251.75 / 1.10^{4}=C U 959.29$.

The day-1 loss (expense) and day-1 loss allowance (contra-asset account) to be recognised would be 1,000.00 959.29 = CU 40.71. The amount of CU 959.29 could be said to reflect initially-expected credit losses twice: within the cash flows, which are stated net of those initially-expected losses, and within the discount rate of $10 \%$, which includes a premium to compensate for those initially expected losses. If the portfolio were to be written down immediately (at day 1) to CU 959.29, it would be stated at below the fair value of CU 1,000.00.

Note: The situation depicted here is different from one in which a loan is made on favourable terms such that the fair value of the expected recoverable amounts is less than the amount lent. It is uncontroversial that, in such circumstances, the loan should be written down to fair value at day 1 . 